Johannessen, Janne Bondi. 2016. Prescriptive infinitives in the modern North

Germanic languages: An ancient phenomenon in child-directed speech.

Nordic Journal of Linguistics 39(3), 231-276.

This is an Open Access article distributed under the terms of the Creative Commons Attribution-NonCommercial License (http://creativecommons.org/licenses/by-nc/4.0/), which permits unrestricted non-commercial use, distribution, and reproduction in any medium, provided the original work is properly cited.

\title{
Prescriptive infinitives in the modern North Germanic languages: An ancient phenomenon in child-directed speech
}

\section{Janne Bondi Johannessen}

\begin{abstract}
The prescriptive infinitive can be found in the North Germanic languages, is very old, and yet is largely unnoticed and undescribed. It is used in a very limited pragmatic context of a pleasant atmosphere by adults towards very young children, or towards pets or (more rarely) adults. It has a set of syntactic properties that distinguishes it from the imperative: Negation is pre-verbal, subjects are pre-verbal, subjects are third person and are only expressed by lexical DPs, not personal pronouns. It can be found in modern child language corpora, but probably originated before $\mathrm{AD} 500$. The paper is largely descriptive, but some theoretical solutions to the puzzles of this construction are proposed.
\end{abstract}

Keywords: child-directed speech, context roles, finiteness, imperatives, negation, North Germanic languages, prescriptive infinitives, subjects, word order

Janne Bondi Johannessen, University of Oslo, MultiLing \& Text Lab, Department of Linguistics and Scandinavian Studies, P.O. Box 1102 Blindern, N-0317 Oslo, Norway.

jannebj@iln.uio.no

\section{INTRODUCTION}

This paper describes a construction that is largely unknown in an otherwise wellstudied language family, even though it has been used since ancient times. While it is well known that North Germanic languages have imperatives, it is not known that they also have a second class of PRESCRIPTIVE INFINITIVES with their own grammatical and pragmatic constraints. The word 'prescriptive' indicates that the function of this infinitive is to state a command, instruction, order or request, i.e. a jussive function.

Imperatives in the North Germanic languages - Danish, Faroese, Icelandic, Norwegian and Swedish - typically have a form that is identical to the verb stem (though with additional person suffixes in the case of Icelandic and Faroese), i.e. they are identical to those infinitives that have a word-final vowel as part of their stem, and are shorter than those infinitives that have a vowel suffix. The picture is complicated somewhat by the well-known fact that for some verb classes in some of the languages or dialects, the imperative has the form of the infinitive. 
What I will show in this paper, however, is that all these languages have a full, thriving set of infinitives used in a prescriptive context alongside the imperatives. These infinitives constitute the only verb of the sentence in which they are contained, and are thus as independent as imperatives and finite verbs generally, and very different from other uses of the infinitive, which are limited to embedded contexts. They are used in a very limited pragmatic context of a pleasant atmosphere by adults towards very young children, or towards pets or adults that are (perhaps temporarily) on a lower point in the social hierarchy than the speaker. These 'child-directed prescriptive infinitives' have a set of syntactic properties that distinguish them from imperatives: Negation is always pre-verbal, subjects are pre-verbal, subjects are third person, and are generally expressed by lexical words, not personal pronouns. ${ }^{1}$ An example is presented in (1). (Here and elsewhere the imperative form of the verb is provided for comparison.)

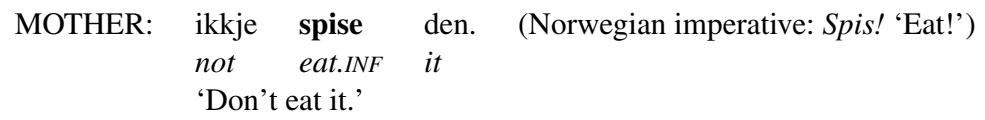

(Anderssen Corpus)

These child-directed infinitives can be found in child language corpora, and are probably used by most native speakers when the appropriate context arises. The fact that the same characteristics are shared by all the languages indicates that the childdirected prescriptive infinitives have existed since before the languages separated, i.e. since before AD 500 .

The paper starts by presenting the standard imperatives (Section 2), with the basic facts on the order of negation and the presence and position of subjects. Section 3 presents the child-directed prescriptive infinitives, and provides authentic examples from a number of sources, including child language corpora. It discusses the pragmatics of the construction, and then looks at the syntactic differences between prescriptive infinitives and imperatives, dealing with the position of negation and subject, and the type of subjects that are possible. It also contains a short discussion of the age of this construction. Section 4 presents some other prescriptive infinitival constructions in the North Germanic languages, showing that these are not the same as the child-directed prescriptive infinitives. Section 5 presents prescriptive infinitives in other languages, arguing that while they may have formal characteristics in common with each other and the child-directed prescriptives, they do not share the same pragmatic constraints. Section 6 provides a discussion of theoretical points that can be drawn on the basis of the new empirical material constituted by the prescriptive infinitives, and an account incorporating syntax and context roles will be given. Section 7 concludes the paper. 


\section{STANDARD IMPERATIVES IN THE NORTH GERMANIC LANGUAGES}

The imperative in the North Germanic languages is generally identical to the stem of the verb, and the general word order when negation is involved, is imperativenegation (though Norwegian differs somewhat from the latter generalisation). Based on examples from the reference grammars of Swedish, Danish and Norwegian, the word order involving imperatives and negation is as shown in (2)-(4). (Here and elsewhere bold print highlights the words that are relevant in the sentence.)
$\begin{array}{llllll}\text { a. Kom } & \text { inte hit med dig! (Swedish) } \\ \text { come.IMP } & \text { not } & \text { here with you } & \end{array}$
'Don't come here, you.'
b. 'Inte kom hit med dig! (Swedish) not come.IMP here with you
'Don't come here, you.'

(Teleman, Hellberg \& Andersson 1999:2777)
a. Bliv ikke narret!
become.IMP not fooled
'Don't be fooled!'
b. *Ikke bliv narret!
not be. IMP fooled
'Don't be fooled!'
(Danish)
(Danish)

(Hansen \& Heltoft 2011:731)
(4) a. Gå ikke over veien...! (Norwegian)
go.IMP not across road.DEF
'Don't go across the road...!'
b. Ikkje reis! (Norwegian)
not go. IMP
'Don't go!'

(Faarlund, Lie \& Vannebo 1997:590, 874)

Thus, in Swedish and Danish, the imperative is the first word in the sentence, with negation following the imperative verb, V-Neg, while in Norwegian, both V-Neg and $\mathrm{Neg}-\mathrm{V}$ are possible word orders. It should be mentioned that according to Platzack \& Rosengren (1998:214), colloquial Danish actually does not have negation in imperatives at all. (Instead they use the alternative phrase: Lad vare med, lit.: 'let be with', meaning 'don't'.) Garbacz \& Johannessen (2013) show that these generalisations are supported by spontaneous speech data and by a grammatical survey for Swedish and Norwegian (Danish was not investigated to he same extent), using the Nordic Dialect Corpus (Johannessen et al. 2009) and Nordic Syntax Database (Lindstad et al. 2009), but that it is the Neg-V order that is most acceptable and most used in Norwegian. 
The Faroese reference grammar shows that there are two inflected imperative forms in this language, one in the singular and one in the plural (Thráinsson et al. 2004), see (5):
a. Far til hús! (Faroese)
go.SG.IMP to house
'Go home!' (to one person)
b. Farið til hús!
go. PL.IMP to house
'Go home!' (to more than one person)

(Thráinsson et al. 2004:68)

If the imperative is negated, the negation is post-verbal, as in (6): ${ }^{2}$
(6) Far ikki heim! (Faroese)
go.SG.IMP not home
'Don't go home!'

(Petersen 2008:141)

Icelandic imperatives can be found only in the singular form, as in (7a) below. In very formal contexts they can be followed by a pronoun, as in ( $7 b)$. The most common way of expressing the imperative, though, is with a reduced form of the second person pronoun attached to the imperative verb (Thráinsson 2007:6-7), as in (7c).

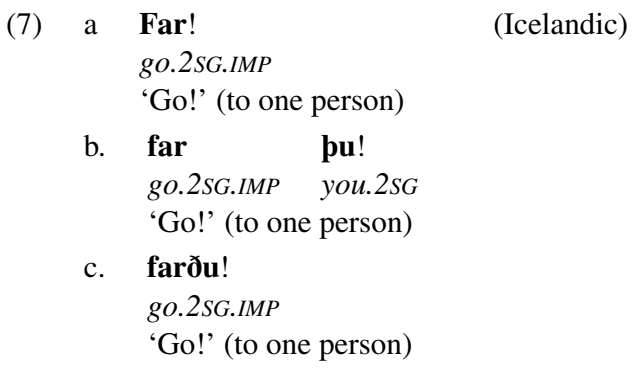

(Thráinsson et al. 2007:6)

Like in Faroese, negation in Icelandic follows the imperative (but more variation will be presented in Section 4), (8).

(8) Láttu ekki svona drengur! (Icelandic) let.2.SG.IMP not thus boy

'Don't behave like that, boy!'

(Blog: http://jennystefania.blog.is/blog/jennystefania/entry/1229102/) 


\section{CHILD-DIRECTED SPEECH}

This section presents prescriptive infinitives in the North Germanic languages, and then discusses how they differ pragmatically and with respect to word order from ordinary imperatives. Finally a short discussion of the age of this construction is presented. To the extent that it has been possible, data have been taken from spoken language corpora.

\subsection{Prescriptive infinitives}

Somebody listening to a parent talking to their toddler in any of the North Germanic languages will soon realise that their language contains prescriptives that are not imperatives, but infinitives. This pan-North Germanic class of prescriptives has not been previously studied, though the use of the infinitive with prescriptive function is briefly mentioned in Hansen \& Heltoft (2011) for Danish, and in Collberg \& Håkansson (1999) and Teleman et al. (1999) for Swedish.

\subsubsection{Norwegian}

Transcriptions from dialogues between parents (and interviewers) and toddlers in a Norwegian part of the Childes Corpus, the Anderssen Corpus of Northern Norwegian Child Language, and the N-LARSP corpus ${ }^{3}$ show a sizeable number of prescriptive infinitives. Some examples are given in (9)-(12) below. Since it could otherwise be argued that these infinitives just echo verbs previously used in the context by the children, they are provided with a bit of context.

(9) MOTHER:

... Nora sitte rolig der Nora

Nora sit.INF quietly there Nora

'Nora sit quietly there, Nora.'

(Norwegian imperative: Sitt! 'Sit!')

NORA: nei ...

'No'

(Childes, nora2.cha)

(10) ANNA: $\operatorname{det}[=$ ? det er $]$ vått

'It is wet.'

INVESTIGATOR: ja det er vått.

'Yes, it is wet.' 
MOTHER:

ikkje spise den. (Norwegian imperative: Spis! 'Eat!')

not eat.INF it

'Don't eat it.'

(Anderssen Corpus)

(11) MOTHER:

mamma få en suss

mummy receive.INF/IMP a kiss

(Norwegian imperative: Få! 'Receive!') ${ }^{4}$

'Give mummy a kiss!'

(Anderssen Corpus)

(12) MOTHER:

natta lilly (dokke) sove godt (Norwegian imperative: Sov! 'Sleep!')

night lilly doll sleep.INF well

'Good night, Lilly! Sleep well!'

(N-LARSP corpus)

In (9), the child opposes the command imposed on it, in (10), the conversation is about something other than the eating action that the mother brings in, and in (11)-(12), there is no linguistic context, but the use is clearly prescriptive.

One could ask whether these are really examples of a special construction. Perhaps they are simply examples of a child-like language that parents adopt, one in which there is little or no inflection? This hypothesis can be quickly rejected. The rest of the language spoken by the parents is not child-like, except in some cases where the parent is clearly echoing the child; repeating it verbatim, as seen in (14)(15) below. The example in (13) shows how the mother is using a language of fully inflected forms to the child, here exemplified with a noun correctly inflected with the masculine definite form and a verb in the present tense.

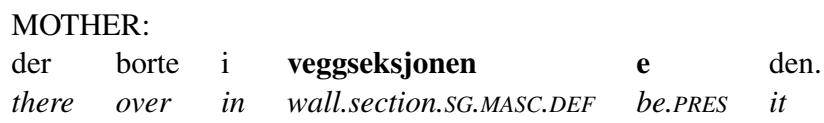

'It is over there in the book case.'

(Norwegian)

(Anderssen Corpus)

Uninflected forms can occur as an echo of something just said in the discourse, as in (14), where the mother repeats what the child has said, and in (15), where the father repeats parts of a modal construction previously uttered by himself, in both cases using a bare infinitival form. These examples do not show anything about the prescriptive infinitives; they simply show that echo utterances are as much part of child-directed speech as they are in other forms of speech. 
(14)

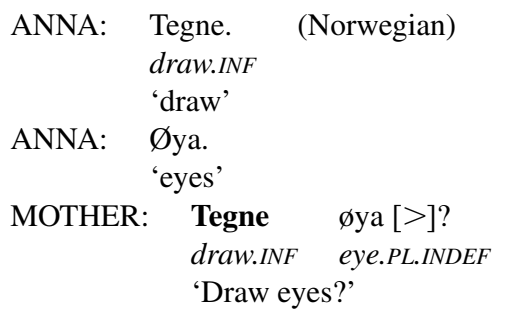

(Anderssen Corpus)

$\begin{array}{rll}\text { (15) FATHER: } & \text { kan du hente kritt? } \\ & \text { can you fetch.INF chalk } \\ \text { FATHER: } & \text { hente kritt! } \\ & \text { fetch.INF chalk } \\ & \text { 'Fetch chalk!' }\end{array}$

(N-LARSP corpus)

\subsubsection{Swedish}

Although in Swedish some verb classes have imperatives with the same form as infinitives (see Section 4 below for more on this), there are some verb classes where they differ morphologically. Swedish child-directed prescriptive infinitives in these classes are like the Norwegian ones. Some corpus examples are given in (16) and (17):

(16) MOTHER:

inte hälla mjölken (Swedish imperative: Häll! 'Pour!')

not pour.INF milk.SG.MASC.DEF

'Don't pour the milk!'

(Childes, ant23_08.cha)

(17) MOTHER:

sätta på locket (Swedish imperative: Sätt! 'Put!') ${ }^{5}$

put.INF on lid.SG.NEUT.DEF

'Put the lid on!'

(Childes, ant26_10.cha)

Like with Norwegian, there is ample evidence that the same parents in the same conversations use ordinary inflected language, and not a simplified variety. Example (18) shows the mother using a verb in the present tense and a noun inflected in the singular masculine definite.

$\begin{array}{ll}\text { MOTHER: } & \text { han sitter ju i bilen } \\ & \text { he sit.PRES yes in } \\ & \text { 'He sits in the car.' }\end{array}$

(Childes, ant24_13.cha) 
A Swedish posting on an Internet forum, answering somebody who asks about the Scandinavian equivalents of the standard Swedish Spring inte! 'run.IMP not' confirms the child-directedness of these infinitives:

(19) Inte springa är om du frågar mig lite mer barnsligt språk, ungefär som när mödrar talar med sina barn eller när man talar med ett djur.

[Inte springa 'not run.INF' is if you ask me a bit more childish language, as when mothers speak to their children or when one talks to an animal.]

(https://www.flashback.org/t1640051)

Teleman et al. (1999) corroborates this by mentioning briefly that an infinitival phrase, normally when negated, can be used prescriptively towards children and animals, as in (20):

(20) Lilla gumman, inte så, inte gråta nu

little woman not so not cry.INF now

(Swedish imperative: Gråt! 'Cry!')

'My little darling, don't cry, please.'

(Teleman et al. 1999:vol.3:595, vol.4:825)

\subsubsection{Danish}

Danish, too, has a prescriptive infinitive in child-directed speech, illustrated in the corpus example (21).

(21) INVESTIGATOR:

tørre din næse. (Danish imperative: Torr! 'Wipe!')

wipe.INF your nose

'Wipe your nose!'

(Childes, anne20_cha)

Example (22) shows that the language towards the children is otherwise inflectionally complex, illustrated here with a noun fully inflected for neuter singular definite.

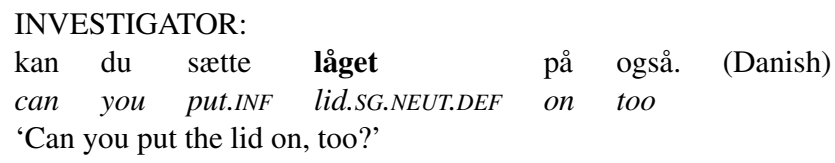

(Childes, anne20_cha)

The infinitive is mentioned in Hansen \& Heltoft (2011:73). They describe it as an infinitival clause that has a modal meaning, and provide a number of examples, of which a couple are reproduced in (23). 

a. ikke græde, lille ven! (Danish imperative: Graed! 'Cry!') not cry.INF little.DEF friend 'Don't cry, darling.'
b. bare vente, ikke! just wait.INF not 'Just wait, please!'
(Danish imperative: Vent! 'Wait!')

(Hansen \& Heltoft 2011:73)

\subsubsection{Icelandic and Faroese}

In Icelandic child-directed speech, too, an infinitive form is used with prescriptive function, (24). There is no Childes Corpus for Icelandic or Faroese, so the data in this paper have been provided by the linguists mentioned with each example.

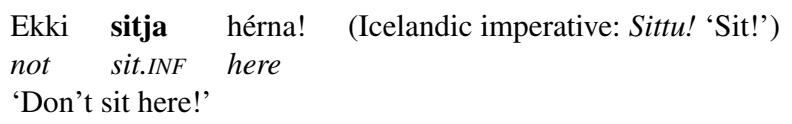

(Birna Arnbjörnsdóttir, p.c.)

\subsubsection{Faroese}

In Faroese, too, this construction is used with children, as in (25).

(25) Ikki fara! (Faroese)
not go.INF
'Don't go!'

(Hjalmar P. Petersen, p.c.)

\subsection{Pragmatic differences?}

A question now is whether the prescriptive infinitives in child-directed speech have different pragmatic functions from the standard imperatives. Could it not just be that child-directed speech should be interpreted as a separate dialect, so that these infinitives have the same pragmatic function in that dialect as the standard adult-to-adult imperatives have in the adult-directed dialect? If the language that parents generally use towards children differs in significant ways from the standard one, a case could be made for an affirmative answer to the question. If, however, other inflectional patterns are the same as in the standard language, it would be more difficult to maintain that child-directed speech is a separate variety. If, further, we find examples of both imperatives and prescriptive infinitives in the child-directed variety, we expect some pragmatic, functional, difference.

Looking closer at the Norwegian, Swedish and Danish corpus data it is clear that the child-directed language is not very different from the standard language: In Section 3.1 we saw that inflections (both verbal and nominal) are present in the 
parent-to-child language. Here we will see that we also find examples of the standard imperatives in the same dialogues as those where we find the prescriptive infinitives (26)-(29), all from the same dialogues where we earlier found the infinitive type.

$\begin{array}{lllllll}\text { MOTHER: } & \text { ja bare } & \text { sitt } & \text { der } & \text { og } & \text { vent } & \text { (Norwegian) } \\ & \text { yes just sit.IMP there } & \text { and } & \text { wait.IMP } & \end{array}$

(The Anderssen Corpus)

$\begin{array}{lll}\text { MOTHER: } & \text { tegn } & \text { her } \\ & \text { draw.IMP here } \\ \text { 'You draw here!' } & \end{array}$

(Norwegian)

(The Anderssen Corpus)

$\begin{array}{lll}\text { MOTHER: } & \text { häll den i munnen } & \text { ja (Swedish) } \\ & \text { pour.IMP it in mouth.SG.MASC.DEF } & \text { yes } \\ & \text { 'Pour it into the mouth, yes!' } & \end{array}$

(Childes, ant23_08.cha)

$\begin{array}{lllllll}\text { MOTHER: } & \text { prøv } & \text { at se hvad Anne laver } & \text { (Danish) } \\ & \text { try.IMP } & \text { to look what Anne does } & \end{array}$

(Childes, anne09.cha)

The data suggest that imperatives and prescriptive infinitives exist side by side, so we should look for a possible pragmatic difference between them. Having studied the child corpus dialogues, it appears that when the adult is upset and possibly annoyed with the child, it is the standard imperatives that appear. The infinitives, on the other hand, are used when the situation is calm and pleasant, in a caring and loving manner. This is further supported by the finding that it is rarely the investigator (unrelated to the child) that uses the prescriptive infinitives; it is usually the parent who does this. They seem to be reserved for a particular use that would sometimes be too intimate for somebody from the outside. This particular pragmatic context cannot be confirmed by references to the literature, given its lack of previous description, but the present author has presented this work at several conferences (see the acknowledgements section) and also talked to many Scandinavian linguists about it. The common reaction to this claim is energetic nodding and a smile of confirmation. ${ }^{6}$

This is not to say that they can only be used in child-directed speech. Any speaker who has a superior position with respect to the listener, and who feels warmly towards them in the conversation, could use these infinitives. The following utterance was overheard used in a friendly manner by an expert on boating and sea to a younger man who had performed a very dangerous swim the year before. The older man wagged his index finger at the younger man, and said (30) with a glimpse in his eye: 
(30)

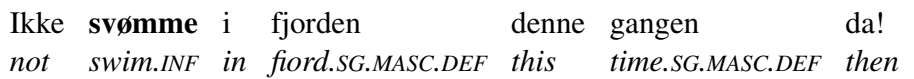

'Don't swim in the fiord this time!'

(Norwegian)

A recent Facebook posting shows something similar. A female lecturer in English linguistics wrote (31) on her wall to Mr. Ari Behn, who is not an academic, but whose claim to fame is his former marriage to the Norwegian Princess Märtha Louise, suggesting that he learn better English. This happened after he had published an article in an English newspaper with a number of spelling errors. She disclosed later that she liked him, which confirms the prerequisite positive attitude suggested in this paper. ${ }^{7,8}$

$\begin{array}{llllll}\text { Men Ari, da. Lære } & \text { seg } & \text { engelsk! } & \text { (Norwegian) } \\ \text { but Ari then teach.INF } & \text { 3SG.REFL } & \text { English } & \\ \text { 'Oh, Ari dear. You should learn English.' } & \end{array}$

(Facebook)

It can also be used towards animals. The following text was found as an illustration in a student newspaper, where a representative in the Students's Parliament comments on the arrival of a new student list, the Trojan List, depicted as a horse in the illustration, (32). A cartoon (with the popular young man Pondus as a protagonist) recently depicted Pondus and his dog, saying (33) to the dog.

(32) Komme da, hesten! (Norwegian)

come.INF then horse.SG.MASC.DEF

'Come on, horse!'9

(Universitas newspaper, 4 February 2015)

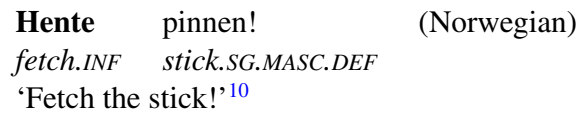

(Pondus cartoon)

Heltoft \& Hansen (2011:738) observe something similar for Danish. They say that the infinitive used in an imperative function marks that the speaker is in a position of strength relative to the receiver, so that it is not always easy to use this infinitival imperative towards adult speakers. ${ }^{11}$ Their example seems to be uttered by a football trainer towards a grown-up player on his team, (34).

$\begin{array}{lllll}\text { spille, mand, } & \text { spille } & \text { bolden, } & \text { for helvede! } & \text { (Danish) } \\ \text { play.INF man play.INF } & \text { ball.SG.MASC.DEF } & \text { for } & \text { hell } & \\ \text { 'Play, man, play the f... ball!' } & & & \end{array}$

(Hansen \& Heltoft 2011:73) 
Without more context it is difficult to tell whether the Danish utterance is said in an agitated mood or in a friendly (and perhaps humorous) atmosphere.

Faroese prescriptive infinitives can also be used towards adults. In those cases, they must be negated (a requirement we also saw has been raised for the Swedish prescriptive infinitives, note 5 , and which has also been reported for some Norwegian dialects and Icelandic, as will be shown in Section 4). The hierarchical social dimension is necessary for the construction to occur. According to Hjalmar P. Petersen (p.c.), (35) is often uttered by his older sister, ten years his senior, to him, but could never be uttered by him towards her:

$\begin{array}{llll}\text { (35) Ikke } & \text { fara } & \text { enn! } & \text { (Faroese) } \\ \text { not } & \text { go.INF } & \text { yet } & \end{array}$

'Don't go yet!'

(Hjalmar P. Petersen, p.c.)

The Icelandic prescriptive can also be used towards adults. There is a pragmatic difference between it and the imperative, in that the latter is more formal (Eiríkur Rögnvaldsson, p.c., and recall also Norwegian in note 8). Thus, (36a) is almost exclusively found in spoken language, in contrast with (36b).

a. Ekki taka pátt i pessu! (Icelandic)
not take.INF part in this
'Do not take part in this!'

(Sigurðsson 2010:36)

b. Taktu ekki pátt i pessu! (Icelandic)
take.INF.you not part in this
'Do not take part in this!'

(Eiríkur Rögnvaldsson, p.c.)

The fact that the prescriptive infinitive is a grammatical form whose use depends on the pragmatic context, is reminiscent of the honorifics in other languages, from Japanese (Okada 1963) and Korean (Lee 1991) to many IndoEuropean languages. Prescriptive infinitives can only be used towards very small children (and animals) or towards people who are very clearly at the lowest point of the relevant hierarchy, and who can accept this fact in a pleasant atmosphere. Without such a mutual understanding of their roles among the participants in the speech event, the prescriptive infinitive would be unbearably condescending. ${ }^{12}$ 


\subsection{Syntactic differences}

\subsubsection{Word order with respect to verb and negation in child-directed speech}

Imperatives and prescriptive infinitives are not just different in morphological form and pragmatic function, but also syntactically. The prescriptive infinitives have preposed negation and typically no subject, while the inflected imperatives in all the North Germanic languages have postposed negation (although Norwegian more often has preposed), (37a-d):
a. MOTHER: ikke skrive i den der (Norwegian) not write.INF in that there
'Don't write in that one.'

(Anderssen Corpus, anna01.cha)

b. MOTHER: *skrive ikke $\mathrm{i}$ den der.

c. FATHER: Ikke klore da får mamma vondt (Norwegian) not scratch.INF then gets mummy pain

'Don't scrath, that'll hurt mummy!'

d. FATHER: *klore ikke da får mamma vondt

(N-LARSP corpus)

In Swedish, imperatives standardly have V-Neg order, like Danish, Icelandic, and Faroese. The child-directed prescriptive infinitives, however, have only preposed negation, (38):

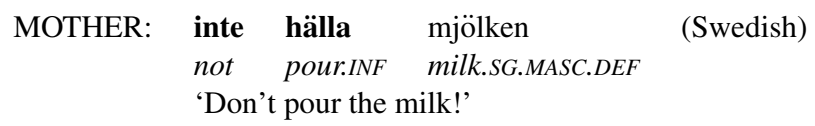

(Childes, ant23_08.cha)

Interestingly we also find this word order in child-directed speech even with the verbs of those verb classes in which there is no formal contrast between the imperative and the infinitive in standard Swedish. This word order would not be acceptable in a nonchild-directed context. Examples of both negated child-directed prescriptives and standard imperatives (found in adult-directed Internet newspapers and magazines) are given below in (39)-(41).
a. MOTHER: inte blanda så! (Swedish prescriptive infinitive) not mix.INF/IMP thus
'Don't mix like that!'

(Childes, ant23_08.cha) 
b. Blanda inte ihop de två skattedebatterna mix.INF/IMP not together the two tax.debate.PL.DEF

(Swedish imperative)

'Don't mix together the two tax debates!'

(http://www.di.se/artiklar/2016/4/8/ledare-blandainte-ihop-de-tva-skattedebatterna/)

(40) a. MOTHER:

nä inte slå honom! (Swedish prescriptive infinitive)

no not hit.INF/IMP him

'No, don't hit him!'

(Childes, tea19_15.cha)

b. Slå inte sönder samarbetet (Swedish imperative)

hit INF/IMP not to.pieces cooperation.N.SG.DEF

'Don't destroy the cooperation!'

(http://nwt.se/asikter/debatt/2016/06/11/sla-inte-sonder-samarbetet)

(41) a. MOTHER:

inte måla i håret! (Swedish prescriptive infinitive)

not paint.INF/IMP in hair.SG.NEUT.DEF

'Don't paint in the hair!'

(Childes, har26_18.cha)

b. Måla inte när det blåser hårt (Swedish imperative) paint.INF/IMP not when it blows hard

'Don't paint when the wind is raging.'

(http://villalivet.se/om-bygg/mala-fasad/)

In Österbottnian Swedish (Finland), pre-verbal negation is also found with prescriptive infinitives. Huldén (1996) notes that this is especially in the language used towards children, (42a). This contrasts with the normal imperatives in this dialect, (42b):
a. It ti
grååt! (Österbottnian Swedish)
not INF.MARKER cry.INF
'Don't cry!'

(Huldén 1996:182)
b. Grååt itt!
cry.IMP not
'Don't cry!'

(Jan-Ola Östman, p.c.)

Although the actual verb form in (42a) looks like a standard imperative form, it is an infinitive; this dialect has apocope, and the imperative form therefore is identical to the infinitive. The two are distinguished by the order of negation and verb, like the Swedish ambiguous examples above and other dialects discussed in this paper, Section 4. 
In Icelandic, there are also verbs that have the same form in imperative and infinitive. Like in Swedish, the position of their negation depends on the pragmatic use. When these verbs are used in child-directed speech, the same word-order pattern as in Swedish occurs, as demonstrated in (43) vs. (44). Negation in Faroese prescriptive infinitives is also preposed, as was shown in (25).

$\begin{array}{lll}\text { Ekki teikna } & \text { hérna! } & \text { (Icelandic child-directed speech) } \\ \text { not draw.INF/IMP } & \text { here } & \\ \text { 'Don't draw here!' } & \end{array}$

(Birna Arnbjörnsdóttir, p.c.)

(44) Teikna bu ekki hérna (Standard Icelandic)
draw.INF/IMP you not here
'Don't you draw here!'

(Birna Arnbjörnsdóttir, p.c.)

Standard Danish, like Swedish, has post-verbal negation with imperatives, to the extent that they can be negated at all, but child-directed Danish, like Swedish and Icelandic, has pre-verbal negation with prescriptive infinitives, (45). It should also be mentioned that some Danish speakers find the prescriptive infinitive to be more acceptable with negation (Tanya Karoli Christensen, p.c.), cf. note 5.

$\begin{array}{lllll}\text { INVESTIGATOR: } & \text { Ikke trykke så hårdt (Danish) } \\ & \text { not push.INF so hard } \\ & \text { 'Don't push so hard.' }\end{array}$

(Childes, anne_10.cha)

All the languages thus have the same pattern, which is that the imperative is (or in the case of Norwegian, can be) negated post-verbally while the child-directed prescriptive infinitive is negated pre-verbally.

\subsubsection{Word order with respect to verb and subject in child-directed speech}

Inflected imperatives typically occur without explicit subjects, with the Icelandic cliticised subjects presented in (7c) being an exception. But when they do occur overtly, imperative subjects are post-verbal in all the languages (Platzack \& Rosengren 1998:218; Eide 2002:232, 2016). We saw an example of an Icelandic post-imperative subject in (7b). An example from spontaneous speech with both negation and a subject is given in (46), and one with a subject only in (47): 


$\begin{array}{llll}\text { Spør du meg ikkje } & \text { (Norwegian) } \\ \text { ask.IMP you me } & \text { not } \\ \text { 'Don't you ask me!' }\end{array}$

(Nordic Dialect Corpus)

Gå du pa bio! (Swedish)
go.IMP you on cinema!
'Go you to the cinema!'

(Teleman et al. 1999:vol.4:710, §35)

It has not been easy to find examples of subjects in the child corpora, probably because they are rare. Below, in (48), is a Norwegian example, repeated from (9), Section 3.1.1, and Swedish has this word order, too, (49). (Note that the subject in these two examples is third person, and is a DP (determiner phrase) rather than a pronoun - these facts will be discussed further in Sections 3.3.3 and 6.)

\begin{tabular}{lll} 
MOTHER: & ... Nora & \multicolumn{1}{c}{ sitte rora } \\
& Nora & sit.INF q \\
& Nora sit quietly there,
\end{tabular}

(Johanna Prytz, p.c.)

It could be argued that Nora and Sara are not subjects here, but rather vocatives. It is difficult to argue against this, since vocatives will always be allowed. Not having access to sound files, these examples are hard to judge, but to the present author, as a native Norwegian speaker, they sound equally good with either intonation pattern. With a subject reading, the name will be pronounced with a high pitch, no break, and with the rest of the clause following in a lower pitch (apart from the last name in (48), which must be interpreted as a right-dislocated element). With a vocative reading, the name would be pronounced in a pitch no higher than the next part of the clause, and there would be an audible break after it.

In Icelandic and Faroese the same contrast is found. While the imperative subjects are post-verbal, those of the prescriptive infinitives are pre-verbal, as illustrated in (56) for Faroese, in Section 3.3.3.

\subsubsection{Subject type: Second or third person}

Subjects of imperatives (called imperative NPs by Platzack \& Rosengren 1998) are normally second person to the extent that they are used at all. In prescriptive infinitives, the subject is often third person, as in the Norwegian and Swedish (48) and (49), respectively, above. Consider also (50), repeated from (31), and (51)-(52). 
(50)

Men Ari, da. Lære seg engelsk! (Norwegian)

but Ari then teach.INF 3.REFL English

'Oh, Ari dear. You should learn English.'

$\begin{array}{lllll}\text { CHILD: } & \text { tegne } & & & \\ & \text { draw.INF } & & & \\ \text { FATHER: } & \text { ja ikkje tegne på } & \text { seg } & \text { sjølv } \\ & \text { yes not draw.INF on } & 3 . R E F L & \text { self } \\ & \text { 'Yes, don't draw on yourself.' } & & \end{array}$

(N-LARSP corpus)

\begin{tabular}{|c|c|c|c|c|c|c|}
\hline FATHER: & $\begin{array}{l}\mathrm{Ja} \\
\text { yes }\end{array}$ & $\begin{array}{l}\text { gjømme } \\
\text { hide.INF }\end{array}$ & $\begin{array}{l}\text { seg } \\
3 . R E F L\end{array}$ & $\begin{array}{l}\text { inni } \\
\text { inside }\end{array}$ & $\begin{array}{l}\text { der } \\
\text { there }\end{array}$ & (Norwegian) \\
\hline
\end{tabular}

(N-LARSP corpus)

Although there is no overt subject in (50)-(52), the third person reflexive shows that the unexpressed antecedent subject is third person. Prescriptive infinitives unlike imperatives thus have third person subjects.

It should be pointed out that the third person subject should not be regarded as an uninflected default subject. Rather, the subject agrees in number with the predicate (the same way that second person subjects do); there is therefore a difference between singular and plural third person subjects, parallel to the way there is between singular and plural second person subjects in imperatives, (53) and (54).
a. Ikke mal deg grønn! (Norwegian imperative)
not draw.IMP 2.SG.REFL green.SG
'Don't paint yourself green!'
b. Ikke mal dere grønne!
not draw.IMP 2.PL.REFL green.PL
'Don't paint yourselves green!'

(54) a. Ikke male seg grønn! (Norwegian prescriptive infinitive)

not paint.INF 3.REFL green.SG

'Don't paint yourself green!'

b. Ikke male seg grønne!

not paint.INF 3.REFL green.PL

'Don't paint yourselves green!'

In Faroese and Swedish, prescriptive infinitives can have either second or third person subject, (55)-(56):

$\begin{array}{llllll}\text { (55) Inte } & \text { skära } & \text { sig / } & \text { dig } & \text { nu! } & \text { (Swedish) } \\ \text { not } & \text { cut } & \text { 3.REFL } & \text { 2.REFL } & \text { now } & \end{array}$

'Don't cut yourself/yourselves now!'

(Johanna Prytz, p.c.) 


Dú/Hjalmar ikke fara! (Faroese)
you/Hjalmar not go.INF
'Don't you/Hjalmar go!'

(Hjalmar Petersen, p.c.)

While Danish and Icelandic may not accept overt subjects in child-directed speech, verbs with reflexives reveal the type of unexpressed, covert subject: ${ }^{13}$

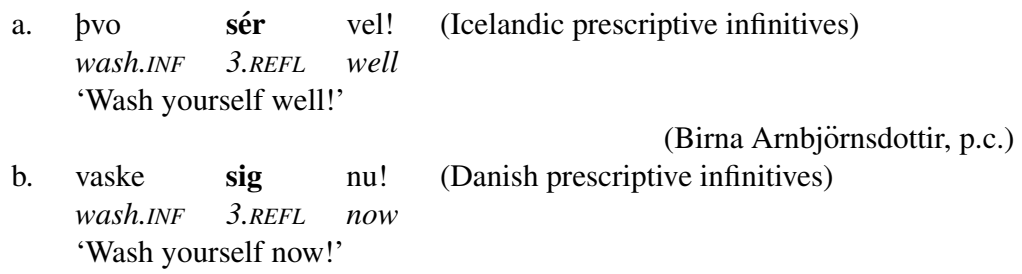

(Tanya Karoli Christensen, p.c.)

It should be mentioned here that the choice of third person subject in the childdirected prescriptive infinitives does not mean that these infinitives are copies of the children's own language. Example (58) (possibly an immature modal construction, where the modal verb is missing and just the infinitive is present) shows an infinitive accompanied by first person personal pronouns. If such pronouns are possible with child-language (elliptical) modals, and they were the model for the child-directed infinitive, we should expect subject pronouns in the latter constructions, contrary to fact.

$$
\begin{aligned}
& \begin{array}{llllll}
\text { LUCAS: } & \text { jeg } & \text { og } & \text { jeg } & \text { og } & \text { reparere } \\
& I & \text { too } & I & \text { too } & \text { repair.INF }
\end{array} \\
& \text { 'Me too, I want to repair.' }
\end{aligned}
$$

(N-LARSP corpus)

\subsubsection{Object type: Third person}

The object, too, shows a preference for third person. Consider (59):
a. Kissa
mammu /
ömmu /
kiss.INF mummy.ACC grandma.ACC
'Kiss mummy/grandma/me!'
?mig
me.1SG.ACC
(Icelandic)
(Eiríkur Rögnvaldsson, p.c.)
b. Susse mamma / ?meg
kiss.INF mummy me.1SG.ACC
'Kiss mummy/me!'
(Norwegian)

In the Swedish (60), the verb belongs to the class that is ambiguous between imperative and infinitive, and there is no negation whose position would help 
disambiguate this form. However, it could be a prescriptive infinitive given that it is uttered by a father who has also used an unambiguous non-negated prescriptive infinitive (recall note 5).

(60) FATHER:

visa nu pappa om du kan lägga pusslet helt själv show.INF now daddy if you can lay puzzle.N.SG.DEF all yourself

(Swedish)

'Now show daddy if you can lay the puzzle all on your own!'

(Childes, ant26_10.cha)

However, although these examples do contain a DP object where ordinary adultdirected language would have a first person pronoun, there seems to be no hard restriction against pronouns in this position, and certainly not like the one for the subject position. In fact child-directed language frequently uses DPs instead of pronouns in all kinds of constructions. They do not occur just with prescriptive infinitives, and certainly not as the only choice of argument. Consider for example the constructed (61):

(61) Mamma/jeg må en liten tur i butikken. Mummy/1SG must a.M.SG.IND little.M.SG.IND trip.M.SG.IND in shop.M.SG.DEF

'Mummy/I must take short trip to the shop.'

(Norwegian)

So the object lexical nouns in the prescriptive infinitives represent an option on a par with pronouns, and not something that is forced upon them for some grammatical reason. ${ }^{14}$

\subsubsection{Summary of the syntactic facts}

A summary of the syntactic facts in imperatives and child-directed prescriptive infinitives is given in Table 1. For all five standard languages, we see that the finite imperatives are $\mathrm{V}-\mathrm{Neg}$; negation is postposed (apart from Norwegian, where negation is preferred pre-verbally). Subjects of finite imperatives, if expressed, are second person, and they are post-verbal.

The child-directed prescriptive infinitives have pre-verbal negation and preverbal subject. The preferred subject is third, not second person. Subjects are normally unexpressed or lexical, not pronouns (but third person reflexive pronouns are $\mathrm{OK})$. 


\begin{tabular}{|c|c|c|c|c|c|c|c|}
\hline & V-Neg & Neg-V & Sub-V & V-Sub & $2 \mathrm{p} \mathrm{Sub}^{\mathrm{a}}$ & $3 p \mathrm{Sub}^{\mathrm{a}}$ & $\begin{array}{l}\text { Pers.pron. } \\
\text { Sub }^{\text {b }}\end{array}$ \\
\hline Danish imp & $(\sqrt{ })$ & & & $\sqrt{ }$ & $\sqrt{ }$ & & $\sqrt{ }$ \\
\hline Faroese imp & $\sqrt{ }$ & & & $\sqrt{ }$ & $\sqrt{ }$ & & $\sqrt{ }$ \\
\hline Icelandic imp & $\sqrt{ }$ & & & $\sqrt{ }$ & $\sqrt{ }$ & & $\sqrt{ }$ \\
\hline Norwegian imp & $\sqrt{ }$ & $\sqrt{ }$ & & $\sqrt{ }$ & $\sqrt{ }$ & & $\sqrt{ }$ \\
\hline Swedish imp & $\sqrt{ }$ & & & $\sqrt{ }$ & $\sqrt{ }$ & & $\sqrt{ }$ \\
\hline Danish pr.inf & & $\sqrt{ }$ & & & & $\sqrt{ }$ & \\
\hline Faroese pr.inf & & $\sqrt{ }$ & $\sqrt{ }$ & & $\sqrt{ }$ & $\sqrt{ }$ & $(\sqrt{ })$ \\
\hline Icelandic pr.inf & & $\sqrt{ }$ & & & $\sqrt{ }$ & $\sqrt{ }$ & $(\sqrt{ })$ \\
\hline Norw. pr.inf & & $\sqrt{ }$ & $\sqrt{ }$ & & & $\sqrt{ }$ & \\
\hline Swedish pr.inf & & $\sqrt{ }$ & $\sqrt{ }$ & & & $\sqrt{ }$ & $(\sqrt{ })$ \\
\hline
\end{tabular}

Abbreviations expanded: Verb-Negation, Negation-Verb, Subject-Verb, Verb-Subject, second person subject, third person subject, personal pronoun subject

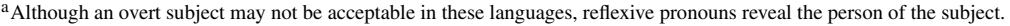

${ }^{\mathrm{b}}$ Parentheses have been used in this column to indicate that these data have not been found in any source independent of the informants, who were uncertain about them.

Table 1. The syntactic differences between imperatives and prescriptive infinitives.

\subsection{On the history of the child-directed infinitival imperatives}

Determining the age of a construction is not easy, especially if we have to go back to a time, more than a thousand years ago, when daily life was not as frequently documented in writing. The child-directed prescriptive infinitives exist across all the North Germanic languages, with largely the same pragmatic and syntactic properties. It is improbable that five languages over such a vast area should have developed, independently in each language, a construction with the same formal and pragmatic characteristics. The most likely history is therefore one of a common origin.

An alternative might have been one of borrowing; that the construction developed first as an innovation in one place and then spread to the rest of the languages in the area. But this is unlikely. If the change had happened after the languages split, they (especially Icelandic and Faroese as against Norwegian, Swedish and Danish) would not have been mutually intelligible, so the borrowing of a particular syntactic phenomenon would be surprising. On the other hand, specific language features, such as the uvular trill $/ \mathrm{R} /$, the development of the perfect verb form and even articles, have been known to spread across very different languages, so borrowings are not totally out of the question. However, for prescriptive infinitives, it is hard to fathom how this construction could have spread, because of its pragmatics. It is mainly used by parents towards little children, and in a nice and pleasant atmosphere, as we have seen. This is not a situation that is typically visible to outsiders, and especially not to people speaking a different language. It is therefore unlikely that it could have spread across such a vast area by way of borrowing. 
One last possibility might have been that the child-directed prescriptive infinitives were a relic of an earlier stage of imperatives, but diachronic facts rule this out. In Section 4 we will see that there are some dialects in Trøndelag, Norway, which have both an inflected imperative and a prescriptive infinitive. According to Haugen $(1982: 99,142,149)$ and Munch (2013), the latter must be newer than the former. Haugen says that while the imperative form in Old Norse was identical to the stem (i.e. our inflected imperative), these forms have now died out in the Oppdal dialect (Haugen 1982:99). Thus, while there are dialects in which prescriptive infinitives are the only jussic alternative, they are actually newer than the imperatives.

The word order Neg-V also seems new for imperatives generally. Munch (2013:260-262) concludes that it is a '(rather new) innovation' in Norwegian, in contrast to V-Neg. The literature suggests that Old Norse had V-Neg order, see Haugen (1982) and Faarlund (2004:228). The Neg-V order is first mentioned in a grammar of the Bergen dialect (Larsen \& Stoltz 1912), according to Munch's findings. Her conclusion is supported by the fact that Aasen's (1864) thorough grammar of Norwegian only mentions the $\mathrm{V}-\mathrm{Neg}$ order with imperatives, as in (62):

$\begin{array}{lllllll}\text { Kom ikkje } & \text { her } & \text { og } & \text { ljug } & \text { fyre } & \text { meg } & \text { (Norwegian) } \\ \text { come.IMP not } & \text { here } & \text { and } & \text { lie. IMP } & \text { for } & \text { me } & \\ \text { 'Don't lie to me!' } & & & & & \end{array}$

(Aasen 1864:319)

It cannot be the case, then, that the prescriptive infinitives have developed from some earlier stage of imperatives. The most likely history of the child-directed prescriptive infinitives is that they have existed in all the languages since before the languages separated, i.e. before $\mathrm{AD} 500$, and probably even long before that. One could ask why there is no documentation of this variety in the written sources from earlier times; the answer probably lies in the genre. The kind of pragmatic context needed for the child-directed imperatives is highly marked, and probably would not be considered suitable in written texts.

\section{OTHER CASES OF PRESCRIPTIVE INFINITIVES IN THE NORTH GERMANIC LANGUAGES}

For the sake of completeness we include some other prescriptive infinitives that exist in the North Germanic languages that do not share all the syntactic characteristics shown in Table 1 above. 
According to Sigurðsson (2010), in Icelandic, infinitives can be used as prescriptives with the constraint that they have to be negated, see (36a), Section 3.2. No pragmatic constraint is mentioned.

Note that this prescriptive infinitive has pre-verbal negation, like the childdirected ones (recall Table 1). This is also the case with another use of the infinitive in Icelandic, where the infinitival marker is present, as in (63), and which it shares with similar examples in some dialects of Swedish and Norwegian (compare the examples from Huldén 1996 in (42a) above and from Munch 2013 in (74a) below). With the ordinary imperative, the negation is post-verbal, as we saw in Section 2 and in Table 1 above.

$\begin{array}{llll}\text { Ekki að } & \text { gráta! (Icelandic) } \\ \text { not } & \text { to } & \text { cry.INF } & \\ \text { 'Don't cry!' } & \end{array}$

(Einarsson 1967:159)

These Icelandic examples and the child-directed prescriptive infinitives might suggest that pre-verbal negation depends on an infinitival form. This should immediately be countered. First of all, we saw in Section 2 that negation in Norwegian imperatives is usually pre-verbal. Further, Petersen (2008) also shows that there is a tendency among young speakers of Faroese to negate their imperatives pre-verbally, as in (64).

\begin{tabular}{|c|c|c|c|c|}
\hline $\begin{array}{l}\text { Ikki } \\
\text { not }\end{array}$ & $\begin{array}{l}\text { sig, } \\
\text { say.SG.IMP }\end{array}$ & $\begin{array}{l}\text { hvat } \\
\text { what }\end{array}$ & $\begin{array}{l}\text { tú } \\
\text { you.SG }\end{array}$ & $\begin{array}{l}\text { hevur ... } \\
\text { have }\end{array}$ \\
\hline
\end{tabular}

(Petersen 2008:146)

Dialects of Swedish and Danish can also have negation preceding the imperative verb. For example, we saw in Section 3.3.1 that Österbottnian Swedish (spoken in Finland), noted by Huldén (1996) can have preposed negation in certain imperative expressions. And according to Pedersen (to appear), most dialects of Danish can have preposed negation, exemplified in (65).

$\begin{array}{llllll}\text { itte jag } & \text { sådan } & \text { på } & \text { med } & \text { det! } & \text { (Danish Fyn dialect) } \\ \text { not hurry.IMP } & \text { so } & \text { on } & \text { with } & \text { it } & \end{array}$

'Don't hurry it so much!'

(Pedersen, to appear)

Infinitives used as prescriptives can also be found without pragmatic constraints in the mainland languages. In these cases they either belong to a subclass of imperatives that happen to have the same form as infinitives due to some historical accident (as mentioned for Swedish in Sections 3.1.2 and 3.4 above, and below), or that they even overlap completely with imperatives for all verbs (as in the Norwegian 
Inntrøndelag dialect, see below). There may also be phonological reasons for a neutralised distinction between infinitives and imperatives (see below for Norwegian). Some of these types will be presented here. Note that these are not pragmatically or syntactically different from other imperatives.

The Swedish standard language and the written Norwegian standard Nynorsk including some Norwegian dialects (Aasen 1848:\$296, 1864:\$236, page 227; Faarlund et al. 1997) have verb classes where the imperative has the same form as the infinitive (the kasta class in Norwegian, Språkrådet 2015). ${ }^{15}$ This is illustrated for Swedish by examples from Teleman et al. (1999:vol. 2:544, §35), who show how some Swedish verb classes distinguish between infinitives and imperatives, (66), while others have the same form, (67).
a. böja $\quad-$ böj (Swedish)
bend.INF bend.IMP
b. binda - bind
bind.INF bind.IMP
a. kasta
(Swedish)
throw.INF/IMP
b. så
SOW.INF/IMP

It is illustrated for Norwegian in (68) and (69).
(68) a. vente $\quad-$ vent (Norwegian Oslo dialect)
wait.INF wait.IMP
b. kaste - kast
throw.INF throw.IMP

(Larsen 1907:83)

(Larsen 1907:83)

(69) a. Kast/kaste/kasta ikkje bort tida

throw.IMP/throw.IMP $(=I N F)$ /throw.IMP $(=I N F)$ not away time.F.SG.DEF

(Norwegian Nynorsk)

'Don't throw away the time.'

(Språkrådet 2015)

b. Smuldr/smuldre/smuldra deigen godt

crumble.IMP/crumble.IMP $(=I N F) /$ crumble.IMP $(=I N F)$ dough.M.SG.DEF well

(Norwegian Nynorsk)

'Crumble the dough well.'

(Språkrådet 2015) 


\section{c. låva (Norwegian Oslo dialect) \\ promise.INF/IMP \\ d. smaka (Norwegian Oslo dialect) \\ taste.INF/IMP}

(Larsen 1907:83)

(Larsen 1907:83)

The Norwegian Oslo dialect is illustrated in (68) with examples by Larsen (1907), with different inflection on infinitives and imperatives. Examples (69a, b) illustrate Nynorsk Norwegian, which has three possible inflections for the imperative of the kasta class, whereas $(69 \mathrm{c}, \mathrm{d})$ illustrate that the old Oslo working class dialect also used the infinitive form with imperatives for some verbs.

In some Norwegian dialects, all imperatives in all verb classes have the same form as their corresponding infinitives (see also Haugen 1982). The Inntrøndelag dialect is a case in point: It has one class of verbs in which bisyllabic words have the same vowel in stem and suffix. It also has a class of mono-syllabic verbs with a circumflex pitch accent, an accent that shows that the words originally had two syllables. Neither class distinguishes formally between infinitives and imperatives, as seen in (70) and (71) (the circumflex accent is annotated with $\mathrm{a}^{\wedge}$ ).
a. låvvå (Inntrøndelag Norwegian)
promise.INF/IMP
b. liggi
lie.INF/IMP

(Arnstein Hjelde, p.c.)
(71) a. ${ }^{\wedge}$ skjøt (Inntrøndelag Norwegian) shoot.INF/IMP
b. $\quad{ }^{\wedge}$ kast
throw.INF/IMP

(Arnstein Hjelde, p.c.)

In all varieties of Norwegian, there is a phonological problem when the verb stem ends in a consonant cluster of rising sonority (Rice 2003), exemplified in (72). The solution varies between dialects and speakers, but one common method is adding a vowel suffix to the stem, thereby obtaining a form that is identical to the infinitive (Rice 2003:377). This does not change the pragmatic and syntactic properties of the imperative. Some example verbs whose imperative is phonologically impossible and that can obtain an infinitival form are given in $(72) .{ }^{16}$ 
(72) åpn $\rightarrow$ åpne 'open'

vitn $\rightarrow$ vitne 'witness'

ordn $\rightarrow$ ordne 'arrange'

kvikn $\rightarrow$ kvikne 'revive'

bobl $\rightarrow$ boble 'bubble'

(Adapted from Rice 2003:374)

Munch (2013:286-287) says that in the Trøndelag dialect area, there are in fact two ways of expressing the imperative, depending on age and dialect. One way would be as in (70)-(71), where there is no difference between the imperatives and infinitives, while another one is like in standard Norwegian, where there is a difference, as described in Section 1. Faarlund et al. (1997:953) says that in many dialects the infinitive can be used instead of the imperative, but only if the clause is negated. This is exemplified as in (73), but the geographical area for this phenomenon is not stated.

$\begin{array}{llrll}\text { Ikkje } & \text { skrike } & \text { så } & \text { fælt! } & \text { (some Norwegian dialects) } \\ \text { not } & \text { scream.INF } & \text { so } & \text { terribly } \\ \text { 'Don't scream so loudly!' }\end{array}$

(Faarlund et al. 1997:953)

There are also infinitives that include not just the infinitive, but also the infinitival marker (as in the Icelandic (63), this section, and Österbottnian Swedish, (42a), Section 3.3.1). Munch (2013:§7.6) has found some examples in the Trøndelag area. These, too, apparently must be negated, see (74) and (75):

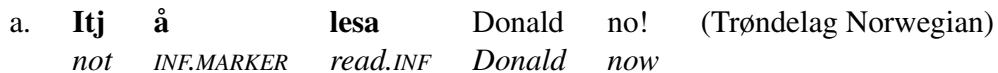
b. Itj lesa Donald no!
not read.INF Donald now
'Don't read Donal Duck now!

(Munch 2013:286)

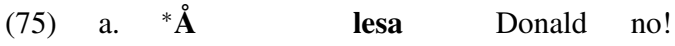 INF.MARKER read.INF Donald now
b. Lesa Donald no! read.INF Donald now 'Read Donald Duck now!

(Munch 2013:286)

The order between verb and negation in the Oppdal dialect of the Trøndelag area seemingly follows the same pattern as in Icelandic and Faroese: If the imperative is expressed by an infinitival verb, the negation is pre-verbal, while if it is expressed by an imperative form, it is post-verbal, see (76): 


a. Ittj jårrå ta
not do.INF
'Don't do that!'
b. Jær ittj ta
$\begin{aligned} & \text { do.IMP not that } \\ & \text { 'Don't do that!' }\end{aligned}$

(Haugen 1982:149)

It should be noted, though, that according to Haugen (1982:99), the original imperative form (the stem form) in the Oppdal dialect has died out in the modern dialect, so that only the infinitive is used nowadays. This would be the same as in the Inntrøndelag dialect above. It also means that the examples in (76) do not represent two synchronic choices with a word order matching the form of the verb, since it represents a historic development, where the word order between negation and verb in (76a) is the same as that for imperatives across Norway.

We have seen that prescriptive infinitives can be found in non-child-directed contexts. In these cases they do not seem to have any particular pragmatic constraints, and neither do they seem to have the constraints on the arguments presented in Section 3. The extent to which the negation is preposed or postposed is not so clearly linked to the imperative-infinitive contrast here. However, there are indications that negation is necessary for the infinitival form to be used. In this respect there is a certain similarity between some of the North Germanic languages and dialects mentioned in this section, and child-directed speech in Swedish and Danish, as described in Section 3. I refer to Zanuttini (1996) for more on the relationship between negation and imperative mood, as this is not limited to the North Germanic languages.

Eide (2002:232) also points out that only the V-Neg order is compatible with a sentential adverb like derfor 'therefore'. Neither subjects nor sentential adverbs can co-oocur with the order Neg-V. The example in (77) illustrates the only possible word orders when the imperative is modified by a sentential adverb and/or is accompanied by a subject. (Parentheses indicate possible pronoun positions.)

$\begin{array}{lcllllll}\text { Kast } & (\mathbf{d u}) & \text { derfor } & \text { ikke } & (\mathrm{du}) & \text { boka } & \text { på } & \text { golvet! } \\ \text { throw.IMP } & \text { you } & \text { therefore } & \text { not } & \text { you } & \text { book.F.SG.DEF } & \text { on } & \text { floor.the }\end{array}$

'Therefore, don't throw the book on the floor.'

(Norwegian)

(Eide 2002:232)

\section{PRESCRIPTIVE INFINITIVES IN OTHER LANGUAGES}

Many other Indo-European languages have some overlap between imperatives and prescriptive infinitives, and this section will present relevant examples from German, French and Polish. In these languages the choice seems to be pragmatically 
determined, though not necessarily in the same way as the North Germanic childdirected prescriptives.

We start looking at German. Duden (1995:§306) shows how the infinitive is used with imperative function, see (78a, b) below, in contrast to the second person singular and plural imperative, as well as the polite third person imperative, see (79):
a. Vorsehen! (German)
plan.INF
'Plan!'
b. Nur nicht frech werden!
just not cheeky be.INF
'Just don't be cheeky!'

(Duden 1995:§306)
(79) a. $\operatorname{trink}[\mathrm{e}]$ !
drink.2.SG.IMP
'Drink!'
b. Geht!
go.2.PL.IMP
'Go!'
c. Schweigen Sie!
shut.up.3PL.IMP $3 P L$
'Shut up!' (Used politely to one or more addressees)

(Duden 1995:§303)

(Duden 1995:§304)

(Duden 1995:§305)

It is remarked in Duden (1995:\$306) that the infinitive in (78a) loses the reflexive pronoun this verb would normally have (sich vorsehen 'plan.INF'). Gärtner (2013) shows several examples of how the infinitive used prescriptively does not have reflexive pronouns. Neither of them mentions that there is a relation between the form of the verb and the negation, but the examples in Duden suggest that the basic facts are the same as in Swedish, Danish, Icelandic and Faroese, where the imperative verbs have post-verbal negation, while the prescriptive infinitives have pre-verbal negation, see (80a, b) (the latter repeated from the beginning of this section, (78b)).

$$
\begin{aligned}
& \text { a. Erschrecke ihn nicht! (German) } \\
& \text { frighten.IMP him not } \\
& \text { 'Don't frighten him!' } \\
& \text { b. Nur nicht frech werden! } \\
& \text { just not cheeky be.INF } \\
& \text { 'Just don't be cheeky!' }
\end{aligned}
$$

(Duden 1995:§306)

An additional point about German prescriptive infinitives is that they cannot be used with transitive verbs that have pronominal objects (Lutz Edzard, p.c.). 
This could be the reason that they occur without reflexives (recall Duden 1995 and Gärtner 2013). Thus, (80a) could not have been replaced by an infinitive.

Pragmatically, the prescriptive infinitive in German is almost the opposite of the North Germanic one. It is used in public notices, and is rarely used in spoken language, perhaps with the exception of military use. It is quite formal, and could even be considered impolite (Lutz Edzard, p.c.).

In French, the imperative and the infinitive are homophonous, but are written differently, and are different syntactically with respect to reflexives and negation, and pattern like Swedish, Danish, Icelandic, Faroese and German. Note that with the infinitive, (82), reflexives and negation are pre-verbal, while with the imperative, (81), the non-consecutive negation is pre- and post-verbal as in other finite verbs, and the reflexive is also post-verbal.

$\begin{array}{lllllll}\text { a. } & \text { Ne } & \text { penche-toi } & \text { pas } & \text { au } & \text { dehors! } & \text { (French) } \\ & N E G 1 & \text { lean.IMP.2.SG-2.SG.REFL } & N E G 2 & \text { to } & \text { out } & \\ \text { b. } & \text { Ne } & \text { penchez-vous } & \text { pas } & \text { au } & \text { dehors! } & \\ & N E G 1 & \text { lean. IMP.2.PL-2.PL.REFL } & N E G 2 & \text { to } & \text { out }\end{array}$

$\begin{array}{lllll}\text { Ne pas } & \text { se } & \text { pencher } & \text { au } & \text { dehors! } \\ N E G 1 \quad N E G 2 & 3 . R E F L & \text { lean.INF } & \text { to } & \text { out } \\ \text { 'Do not lean out!' } & & & \end{array}$

(Helland 2006:331)

The pragmatic use of the French infinitives seems quite similar to that of German. It is found in special contexts, such as recipes, instructions, commands or outbursts (Helland 2006:331).

Polish is exemplified in (83) and (84).

Nie gadać tu! (Polish)
not speak.INF here
'Don't speak here!'

$\begin{array}{lll}\text { Nie } & \text { gadaj } & \text { tu! } \\ \text { not } & \text { speak.2.SG.IMP } & \text { here } \\ \text { 'Don't speak here!' } & \end{array}$

(Paweł Kazimierz Urbanik, p.c.)

Pragmatically, the infinitive is used in a setting where there is a hierarchical social difference between the participants, such as teacher to pupil or parent to child, while it is not used between, for example, spouses or friends. Lubecka (2000:87) expresses the pragmatic constrains as follows: '[i]nfinitives appear when the power distance is big and the request/invitation is to be marked with disrespect, rudeness and even impertinence'. Wierzbicka (1985:154) also stresses the unfriendly pragmatics of the 
Polish infinitive: 'When the speaker gets really angry with the addressee s/he will often avoid the imperative and resort to "stronger" devices, in particular, to the bare infinitive'.

There are many other languages that use infinitives as prescriptives. Aikhenvald (2013:281) mentions Estonian, Russian, Armenian, Modern Hebrew, Turkic languages (exemplified by Yakut), Korean and Spanish. Her generalisation of their pragmatics is that they imply strong commands and prescriptions, i.e. the opposite of our child-directed prescriptive infinitives. However, she says about the Armenian ones that they can only be used 'by a superior to their subordinates', perhaps like Polish. Bennis (2006:fn. 2) mentions that infinitives can be used with imperative force in Dutch. Modern Greek does not have infinitives, but subjunctives can be used as prescriptives (Joseph \& Philippaki-Warburton 1987:18), as can imperfectives in the Slavic languages (Alvestad 2013). It is also common that imperatives cannot be negated by simply adding negation to the structure. Other forms of the verb, typically infinitive or subjunctive, are used in these cases, for example in Greek, Spanish and Italian (Poletto \& Zanuttini 2003; Postma \& van der Wurff 2007; Iatridou 2008:23). Imperatives frequently require other negative and modal particles than declarative structures do.

To conclude this section, prescriptives can be expressed by infinitives in many other languages than the North Germanic ones. While there may be similarities between the position of negation in imperatives and infinitives, and maybe even other comparable word-order facts, between North Germanic and other languages, there seem not to be other syntactic similarities, such as those regarding person categories and subjects, or indeed regarding lexical versus pronominal arguments. Neither does there seem to be the same pragmatic constraints that the North Germanic childdirected prescriptive infinitives have. The fact that the North Germanic languages share characteristics that do not extend to the other Germanic or Indo-European languages should be taken as further support that the child-directed infinitives are indeed an old phenomenon.

\section{THEORETICAL IMPLICATIONS}

The prescriptive infinitives present a series of puzzles that need to be understood. Drawing on relevant literature some solutions will be proposed here.

\subsection{Adressee: Third person and not second person}

We have seen (Sections 3.3.2 and 3.3.3) that child-directed prescriptive infinitives do not have pronominally expressed subjects for the addressee, and that subjects tend to be a third person non-pronominal DP. Exactly how this is encoded 
in the grammar should be investigated. A first step is to study how the relationship between a syntactic function and a discourse context role has been treated in the literature. The most relevant literature will be presented in this section.

Prescriptives (infinitival as well as imperatives generally) have in common that the subject is the addressee. Formalising the relationship between a syntactic category and a contextual role has been proposed in the literature. Sigurðsson (2004, 2014:182) links syntax to pragmatic context, and argues that the person category is a syntactic category. Sigurðsson's theory assigns the person category by computation, so that when an argument is personal (normally not inanimate and not indefinite), and it has a negative value for logophoric agent and a positive value for logophoric patient, it is 'second person by computation'. First person, on the other hand, has a positive value for logophoric agent, and a negative value for logophoric patient. Third person has a negative logophoric value for both agent and patient, or if the argument is non-personal. Sigurðsson formalises it this way:

$$
\begin{aligned}
& \mathrm{NP}_{+\mathrm{Pn}} \rightarrow \mathrm{NP}_{+\mathrm{Pn} /+\mathrm{LA},-\mathrm{LP}}=1 \text { st person by computation } \\
& \mathrm{NP}_{+\mathrm{Pn}} \rightarrow \mathrm{NP}_{+\mathrm{Pn} /-\mathrm{LA},+\mathrm{LP}}=2 \text { nd person by computation } \\
& \mathrm{NP}_{+\mathrm{Pn}} \rightarrow \mathrm{NP}_{+\mathrm{Pn} /-\mathrm{LA},-\mathrm{LP}}=3 \text { rd person by computation } \\
& \mathrm{NP}_{-\mathrm{Pn}} \quad=3 \text { rd person by default }
\end{aligned}
$$

(Sigurðsson 2014:180)

Since Sigurðsson's theory does not take imperatives (or prescriptives generally) into account, it does not predict the right person for the logophoric roles. Subjects are [+Pn/+LA, -LP], i.e. first person by Sigurðsson's theory, while in imperatives they ought to have been computed as second person, and in prescriptive infinitives as third person.

Alcázar \& Saltarelli (2014:Chapter 4), building on work by Ross (1970), Bianchi (2003), Sigurðsson (2004) and Zanuttini (2008:197), propose a syntactic minimalist analysis of imperatives. They, too, formalize the relationship between the syntax and the context. Splitting up the verb into the roles of $\mathrm{A}=$ speaker, $\mathrm{B}=$ addressee and $\mathrm{C}=$ performer, they account for canonical and extended imperatives, respectively, as in $(86 \mathrm{a}, \mathrm{b})$. In canonical imperatives, such as $G o !$, the speaker is first person, while the addressee is the same as the performer, second person. The extended type, on the other hand, for sentences like Let us/him/*you go!, distinguishes between addressee (who must be second person) and performer (who must be first or third person). It is the light verb that assigns the speakers associated with the roles, according to their 'light' performative hypothesis (LPH; Alcázar \& Saltarelli 2014: 111). 
(86)

a. Thematic identification in canonical imperatives

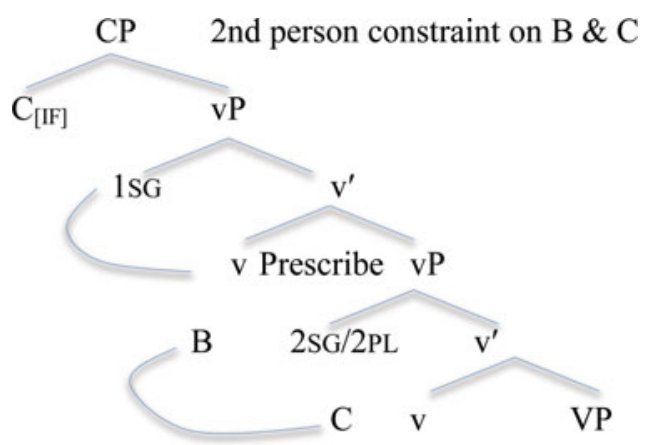

b. Thematic identification in extended imperatives

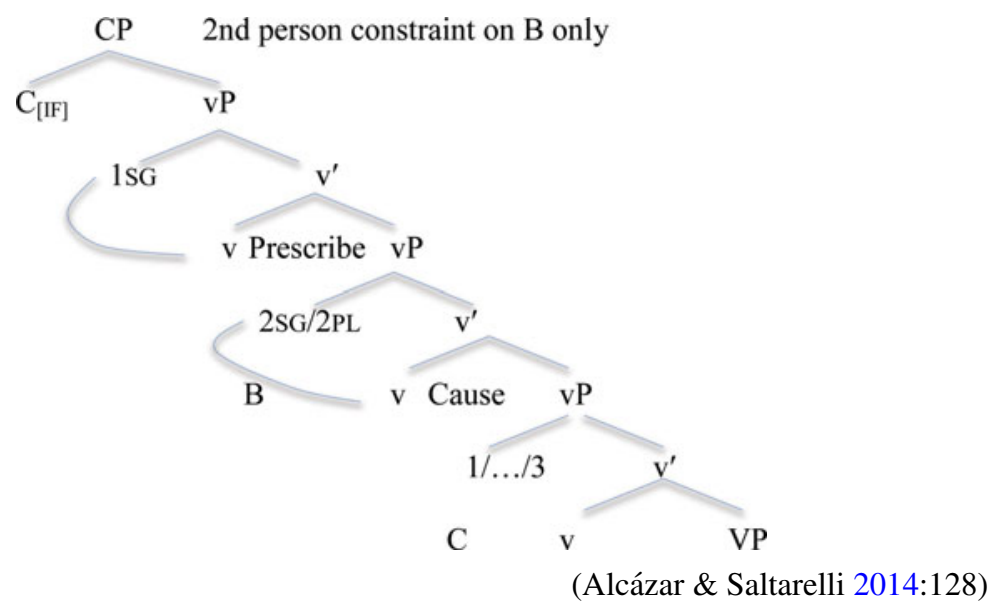

This model has the advantage that it encodes the speech act into the syntax, so the speaker is first person and the addressee second person. Bennis $(2007: \S 5,133)$, too, proposes that second person is part of the actual syntactic structure, specifically as a feature in the imperative C-position. Alcázar \& Saltarelli (2014:111 ex. (5)) take the 'prescribe' label of the $\mathrm{v}$ node in the diagrams to include meanings such as DEMAND, REQUEST and PROHIBITION. However, the computational mechanism that derives person and number restrictions is actually not argued for: 'Thus, under LPH, the Speaker $>$ Addressee relation is ultimately derived as a syntactic dependency theorem, CONCEIVABLY ALONG WITH PERSON (/NUMBER) RESTRICTIONS' (Alcázar \& Saltarelli 2014:117, my emphasis). For prescriptive infinitives, their theorem does not capture the correct generalization, since addressee (B) would need to be third person.

A more fine-grained distinction is needed. We should distinguish between syntactic function (such as subject), syntactic category (pronoun or DP), context 
roles (speaker, addressee, etc.) and syntactic person (such as second or third person). Collins \& Postal (2012), citing work as early as Jespersen (1924), discuss various types of third person DPs, which they call imposters, that are used instead of pronouns, such as in (87a), where the DP replaces a first person pronoun, and (87b) a second person pronoun:

a. This reviewer was unable to follow the logic of the submission.

b. Would the baroness like more wine?

(Collins \& Postal 2012:2)

They provide an analysis which builds on that of appositive structures (such as We, the present writers, disagree with the following points), where both the imposter and the antecedent pronoun are present in the structure.

While Collins \& Postal (2012) propose a way that imposter DPs can be analysed with the correct interpretation, they do not account for the cases where the imposter DPs, as we can call the explicit non-pronominal subjects of our prescriptive infinitives, are obligatorily expressed as imposters, if they are to be expressed at all, as in the subjects in the Norwegian child-directed infinitives.

The integration of syntax and discourse that has been illustrated in this section will be a basis for an analysis of imperatives and prescriptive infinitives in Sections 6.2-6.3.

\subsection{Lack of case: Subject is DP not pronoun}

We have seen that the prescriptive infinitives do not have second person arguments. Instead of following Sigurðsson $(2004,2014)$ and Alcázar \& Saltarelli (2014), who assign person directly as a function of the roles of speaker and addressee, it would be more desirable if this could follow from purely general syntactic facts. The main characteristic of the prescriptive infinitives is that they are infinitival, i.e. they lack finiteness.

Could the finiteness feature be related to the missing first and second person subject? Finiteness has been known to have the property of assigning case (since Chomsky 1980). With null case assignment, an argument is realised as PRO (Chomsky 1995:119-120), typically with infinitives. Other infinitives discussed in the literature are not independent sentences as they are in our case, but are the argument of a verb or an infinitival marker that lays out the conditions for a controlled or a free PRO, or they become part of an ECM construction. Prescriptive infinitives have no higher verb that could licence ECM for their external argument. Neither can they have free PRO: Like imperatives, they have a defined set of agents - speaker, addressee and performer - which follows from their imperative force feature. Prescriptive infinitives have no finiteness projection, so there is no licencer of case. Without case assignment pronouns cannot be licenced, since they are the only category 
in Norwegian that has overt case-marking. This is particularly true for first and second person pronouns, whose case distinctions are kept distinct in most dialects, in contrast to the third person, in which the morphological case contrasts have disappeared both in the singular and the plural. Lexical words, on the other hand, are not case-marked in the vast majority of Norwegian dialects, and proper names are never case-marked. It could be, therefore, that lack of overt case-assignment by a finiteness feature excludes case-marked pronouns from the prescriptive infinitives.

The proposal makes a prediction: A pronoun (overtly case-marked) can never be the subject of the prescriptive infinitive. Up to this point we have assumed that there is some kind of ban on the second person categories for the infinitival participants, since the arguments must be lexical DPs. But we have not considered third person pronouns, which fare no better, compare the authentic (88a) (repeated from (9) above) with the constructed $(88 \mathrm{~b})$.
a. ... Nora sitte rolig der Nora (Norwegian)
Nora sit.INF quietly there Nora
'Nora sit quietly there, Nora.'
b. *Hun sitte rolig der!
she.NOM sit.INF quietly there
'She sit quitely there!'

(Childes, nora2.cha)

It is PRONOUNS that are the problem, not the person category. And as we have seen, lexical DPs, and more specifically names and name-like nouns such as mamma 'mother', as arguments are fully acceptable. What distinguishes pronouns from lexical words is that the latter have no expression of morphological case. $^{17,18}$

It should be clear from the above that the term 'morphological case' does not mean 'inherent morphological case', for which the dative subjects in Icelandic are typical representatives, but 'structural, morphological case' (see Sigurðsson 2001). Sigurdsson (2001:18) stresses that even if an argument has structural case, or is argument-licenced, as he calls it (and which is done via vP), and even if it is a case-marking language, it does not have to mark the argument DPs this way. This can be seen in Icelandic dative subjects, and it can be seen in the prescriptive infinitives. With Legate (2008) it can be assumed that the morphologically unmarked nouns in the prescriptive infinitive are marked by a default case, inserted because the morphological case-marking (and hence the availability of having pronouns), is unavailable. There would then be a sharp distinction between morphological case and no case. Abstract case is not relevant. This is in accordance with the arguments posited by McFadden (2008) and Sundaresan \& McFadden (2009). 


\begin{tabular}{llll}
\hline & \multicolumn{2}{c}{ Subject } & \\
\cline { 2 - 4 } & $\begin{array}{l}\text { Morphologically } \\
\text { case-marked }\end{array}$ & Null case & $\begin{array}{l}\text { Reflexive } \\
\text { object }\end{array}$ \\
\hline Addressee $\neq$ speaker & $d u$ & PRO[2SG]/Caseless DP[3SG] & deg/seg \\
\hline Addressee $\neq$ speaker & dere & PRO[2PL]/Caseless DP[3PL] & dere/seg \\
\hline
\end{tabular}

Table 2. Assignment of person to the subject and object arguments of finite imperatives and prescriptive infinitives.

However, there is an understood subject argument in the prescriptive infinitives even if it is not phonologically realised. We have seen this in the examples where there is a third person reflexive object ((54), (55) and (57), Section 3.3.3), which must mean that the subject argument is third person. Prescriptive infinitives would have a PRO that is controlled, not by an explicitly mentioned argument, but by the arguments provided by the speech act: speaker, addressee and performer.

The imperative force in $\mathrm{C}$ assigns participants of the event, and the phonological realisation of their person values depends on whether they are pronounced or not. Table 2 summarises the person features for both imperatives and prescriptive infinitives.

\subsection{Infinitives, future tense and context roles}

It has been discussed in the literature whether infinitives have tense and in what way. Wurmbrand (2014) argues that infinitives do not have tense, even the type that has usually been called (from Stowell 1982 to Landau 1999, 2000) future irrealis infinitive, (89a), in contrast to the propositional (89b):
a. Leo decided to read a book.
b. Leo believes Julia to be a princess.

(Wurmbrand 2014:404)

The future infinitive has been held to have the following characteristics: It has tense, controlled subject, null case, episodic interpretation. Landau also adds agreement to this list. The infinitives that are tenseless from a traditional point of view, have ECM subjects, and cannot have episodic interpretation.

Wurmbrand shows (2014:410) that it is wrong to assume that there is a built in future tense in the future infinitives, since it is possible to use them for past events, as in (90a), contrasting with the finite clause in (90b). This shows that infinitives have relative tense, while finite verbs have an absolute tense. 
(90) a. Leo decided a week ago to go to the party yesterday.

b. Leo decided a week ago that he will go to the party (*yesterday).

(Wurmbrand 2014: 411)

Wurmbrand suggests, following Abusch $(1985,1988)$, that future is a composite category, involving a future modal woll. This way the tense of infinitives can be relative, as we have seen they are - note past tense in (90a). In (91) below, the difference between finite and non-finite future is depicted. Note the absence of the $\mathrm{TP}$ projection in the non-finite future.

a. Finite future

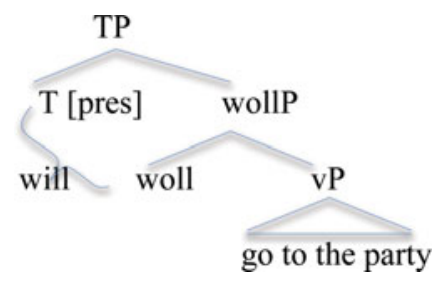

b. Non-finite future

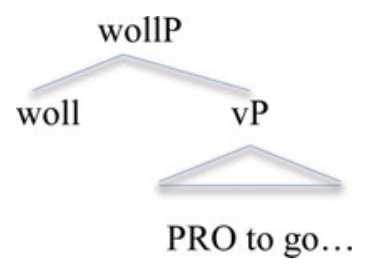

(Wurmbrand 2014:413)

Unlike other infinitives, prescriptive infinitives (and the imperatives) refer to an absolute future. Wurmbrand (2014) does not discuss imperatives or prescriptive infinitives. However, imperatives must be finite, and must have an absolute, not relative, future. But finite imperatives cannot have a morphological merger of $\mathrm{T}_{[\mathrm{pres}]}$ and woll into will, as she proposes. Her idea is well suited for declarative finite clauses, where this merger can actually be spelt out as will in sentences like (90b). It seems less suitable as an analysis of a sentence type like imperatives, which are never spelt out with a modal verb. A possible suggestion is that [+fut] is a feature in T. Abusch's (2004) proposal is semantically rendered as $\lambda P \lambda t P(t, \infty)$, i.e. a point in time unconstrained from time $t$. Given that imperatives have absolute future, and that child-directed prescriptive infinitives in addition to this have a rather immediate scope, the present author suggests that [+fut] is rendered as a special case of Abusch: $\lambda P . P($ now, straight after $) .{ }^{19}$

The prescriptive infinitive is derived in a similar way, but without a finiteness feature, and hence nothing that makes this into anything other than an infinitive, albeit with imperative force. 
In the present proposal, the category TP is where tense resides and is an anchoring category, with Ritter \& Wiltchko (2014:1334). The tree in (92), proposed by the present author, is actually the same as their syntactic spine, with the difference that their label is IP rather than TP, which reflects the main argument of their paper; that IP is a very general category that can be instantiated by different languagespecific, deictic anchoring contents such as tense, location or participant. In the present proposal it is the imperative force in $\mathrm{C}$ that is responsible for the future tense in T, which is very similar to Ritter \& Wiltchko (2014:1369-1370), who posit that $\mathrm{T}$ is valued as [+coincidence] (the event situation coincides with the plan set). The roles of speaker, addressee and performer in (92)-(93) are represented by A, B and C, respectively, following Alcázar \& Saltarelli (2014). Notice that it is significant in the present proposal that $\mathrm{A}$ and $\mathrm{B}$ are not specified as being a particular person (unlike Alcázar \& Saltarelli, who posit that A is encoded as 1SG and B as $2 \mathrm{SG} / 2 \mathrm{PL}$, see (86) above). $\mathrm{B}$ is usually the same as $\mathrm{C}$, but there are some verbs in which the performer is somebody else, like the Norwegian verb $f a ̊$ 'receive', see example (11) above, Section 3.1.1, in which the one who receives $(=\mathrm{C})$ is the speaker $(=\mathrm{A})$.

Ordinary finite imperatives

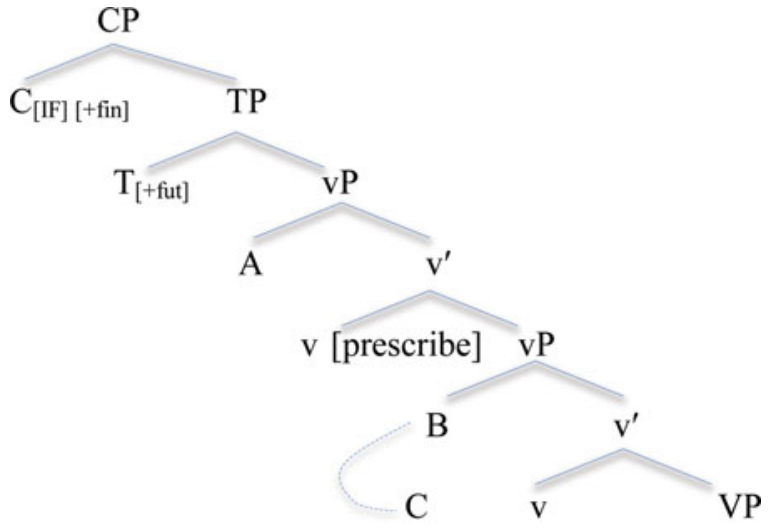

Ritter \& Wiltchko (2014:1351-1354) take infinitives to be tenseless and to get their tense from the predicate above. With a feature [+coincidence], the IP of infinitives gets the same tense as the predicate above, while with a [-coincidence] feature, the infinitive must be interpreted as future, see also Wurmbrand's (2014) account. This is different from the present proposal, in which the future tense in $\mathrm{T}$ is determined by the imperative force in $\mathrm{C}$, just as with finite imperatives. 


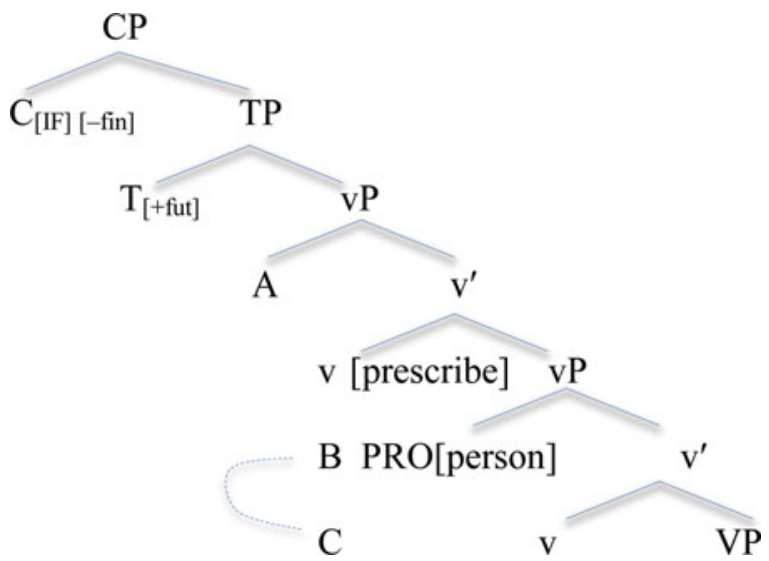

The finite imperative resides in $\mathrm{C}$, while the infinitive verb resides in $\mathrm{T}$. This explains most of the word order facts as well: Infinitives have categories like adverbs and subjects to their left, while imperatives have these categories to their right.

Eide $(2009,2011,2016)$ has developed a classification of Norwegian verb forms according to the minimal features they contain. These are [ \pm Finiteness] and $[ \pm$ Tense $]$. It seems that $[ \pm$ Irrealis $]$ should be added to this set of features. The irrealis feature in the grammar of Norwegian has been pointed out in recent years by Sandøy (1991), Dørum (2000), Julien (2003) and Eide (2011). The [+Irrealis] feature typically reflects hypothetical or counterfactual meanings, and it has been shown by the authors mentioned that these are morphologically encoded, even in modern Norwegian, which no longer has a fully productive subjunctive. [ \pm Irrealis] is also a category that could be used to unify the two directive types imperatives and prescriptive infinitives. Neither can be used to ascertain that something has actually happened or is actually the case. Rather, they are expressions that contain some uncertainty as to whether the desired event will ever take place. The matrix of Norwegian verb features is thus proposed to be as Table 3.

\subsection{Word order: The position of negation and subject}

As seen in Section 3 (and partly in Sections 4 and 5) above, prescriptive infinitives only have pre-verbal negation, while inflected imperatives have post-verbal negation (though Norwegian also has pre-verbal negation). This implies that finite imperatives move further, possibly to $\mathrm{C}$, due to their finiteness feature. This way they move past the position of negation (adjoined to TP), see Zanuttini (1996), Platzack \& Rosengren (1998:213) and Lindstad (2007:Chapter 5). Prescriptive infinitives, being non-finite, do not move, and thus the negation ends up being pre-verbal. When Norwegian finite imperatives can also have pre-verbal negation, it may be because they can go to 


\begin{tabular}{lllllll}
\hline & + Finite & -Finite & + Past & -Past & +Irrealis & -Irrealis \\
\hline Finite imperative & $\sqrt{ }$ & & & $\sqrt{ }$ & $\sqrt{ }$ & \\
$\begin{array}{l}\text { Child-directed present } \\
\text { infinitive }\end{array}$ & & $\sqrt{ }$ & & $\sqrt{ }$ & $\sqrt{ }$ & \\
\hline Preterite & $\sqrt{ }$ & & $\sqrt{ }$ & & & $\sqrt{ }$ \\
\hline Past participle & & $\sqrt{ }$ & $\sqrt{ }$ & & & $\sqrt{ }$ \\
\hline Present & $\sqrt{ }$ & & & $\sqrt{ }$ & $\sqrt{ }$ \\
\hline Infinitive & & $\sqrt{ }$ & & $\sqrt{ }$ & \\
\hline
\end{tabular}

Table 3. Expanded table of feature distinctions for verbs. (The original distinctions from Eide $(2009,2011,2016)$ are shown here in the shaded cells.)

the general topic position of the clause; [Spec, CP]. It is not clear why the other Scandinavian finite imperatives cannot also have a topicalised negation in [Spec, $\mathrm{CP}$. However, it is known that Norwegian generally allows negation in this position, also in declaratives, not just imperatives.

The same general movement can be assumed to explain the position of the subject: The finite verb moves past it, while the non-finite prescriptive infinitive stays in situ.

\section{CONCLUSION}

The paper describes a hitherto largely unknown, full set of prescriptive infinitives in all the five North Germanic languages (Danish, Faroese, Icelandic, Norwegian, and Swedish). These infinitives exist side by side with the well-known imperatives. They differ from finite imperative constructions in a number of ways syntactically, by having (i) pre-verbal, not post-verbal, negation; (ii) pre-verbal, not post-verbal, subjects; (iii) third, not second, person subjects; and (iv) lexical DP, not pronominal, subjects. They also have special pragmatics, in that they can mainly be used in a hierarchical social context in which there is a nice and amiable atmosphere, typically parents towards very young children.

A number of theoretical implications have been suggested. The child-directed prescriptive infinitive is a $\mathrm{CP}$, but with no finiteness, unlike ordinary imperatives. This accounts for all the syntactic differences between the finite imperative and the prescriptive infinitive. The account builds on insights from Sigurðsson $(2004,2014)$, Collins \& Postal (2012), Alcázar \& Saltarelli (2014), Ritter \& Wiltschko (2014) and Wurmbrandt (2014).

Since all five North Germanic languages have the child-directed prescriptive infinitive, the null hypothesis is that it originated before the languages split, i.e. before $\mathrm{AD} 500$. Otherwise, an unlikely process of innovation and spread would have 
to be accounted for. It is therefore argued that the prescriptive infinitive is a category that has existed for more than 1500 years, though its existence and especially its grammatical and pragmatic characteristics in a common North Germanic perspective have gone mostly unnoticed.

\section{ACKNOWLEDGEMENTS}

I am grateful to the participants at Grammatik i fokus 2013 at Lund University, especially Lars-Olof Delsing, Verner Egeland, Elisabet Engdahl, Gunlög Josefsson, Ida Larsson, Johanna Prytz and Anna-Lena Wiklund for providing information on Swedish. I am also grateful for helpful comments by the participants at the 25 th Scandinavian Conference of Linguistics 2013 at University of Iceland, especially Eefje Boef, Piotr Garbacz, Hans-Martin Gärtner, Marit Julien and Rafaella Zanuttini, and by the participants at the Norwegian linguistics conference MONS 15, University of Oslo, 2013. I would also like to thank the participants at the Forum for Theoretical Linguistics at the University of Oslo, February 2015, for valuable feedback: Silje Alvestad, Atle Grønn, Kjersti Kola, Signe Laake, Per Erik Solberg, Bror Sviland Strand, Kjell Johan Sæbø, Ingebjørg Tonne, Urd Vindenes and Arnfinn Muruvik Vonen. I am also grateful to the audience at my guest lecture at the University of Cambridge in February 2015, especially: Theresa Biberauer, Tam Blaxter, Kari Kinn, Ian Roberts and Richard Stockwell. A number of other linguists have also provided information: Jan-Ola Östman on Finland Swedish; Thórhallur Eythórsson, Eiríkur Rögnvaldsson and Birna Arnbjörnsdóttir on Icelandic; Tanya Karoli Christensen and Karen Margrethe Pedersen on Danish; Arnstein Hjelde on the Norwegian Inntrøndelag dialect; Zakaris Svabo Hansen, Petra Eliassen and Hjalmar P. Petersen on Faroese; Lutz Edzard on German; Guri Bordal on French; and Paweł Kazimierz Urbanik on Polish. Special thanks are due to Professors Helge Lødrup and Ida Larsson, who provided detailed and constructive comments on an earlier version of this paper. Finally I would like to thank the three anonymous reviewers and $N J L$ editor Marit Julien for valuable and insightful comments, and copy-editor Ewa Jaworska for her very thorough work and helpful suggestions. This work was partly supported by the Research Council of Norway through its Centres of Excellence funding scheme, project number 223265 .

\section{NOTES}

1. One reviewer would like to see the discussion in this paper in the context of prohibitives as they are presented in WALS Online (http://wals.info/chapter/71). I cannot see that this is directly relevant. The chapter The Prohibitive by van der Auwera \& Lejeune with Goussev (2013) gives a nice overview of ways that prescriptives vary formally across languages, with a special focus on how they differ from declaratives. The present paper deals with a 
specific type in one language group, and focuses on how it differs from the imperatives in the same languages. They do not have to be negative, and are hence not necessarily prohibitive.

2. This may be about to change. Petersen (2008) reports that young people often use preverbal negation. (See also Section 4.)

3. I am grateful to Bror-Magnus Sviland Strand for providing me with examples from the $\mathrm{N}$-LARSP corpus.

4. It cannot be determined morphologically whether $f a ̊$ 'get' is infinitive or imperative in this context, since verbs ending in a vowel do not vary between these forms. But since imperatives do not normally have explicit subjects, and certainly never third person subjects, this must be a case of infinitive. The imperative $f a ̈$ ' $g$ get' has an unusual argument structure, in that the subject is not the performer, but the recipient of the verb. The adressee is the performer, but the performative verb is never mentioned.

5. Additionally, it should be mentioned that for some speakers (Elisabet Engdahl and Ida Larsson, p.c., and mentioned by Teleman et al. (1999:vol.3:595, vol.4:825), see Section 3.1.2 above, related to example (20)), the prescriptive infinitives should be preceded by an adverb, preferably negation, and would be unacceptable without one. However, the Childes Corpus shows examples without adverbs, too, in (17) as well as in (i).

$\begin{array}{llllll}\text { (i) FATHER: } & \text { skjuta } & \text { till den } & \text { så } & \text { (Swedish) } \\ & \text { slide.INF } & \text { to } & \text { it } & \text { then } & \end{array}$

'Slide it then!'

(Childes, ant26_10.cha)

6. One reviewer would like quantitative measures of the use of the prescriptive infinitive as it occurs in the corpora. I have not attempted to quantify the occurrences and do not see that it would be helpful. There are not many recordings altogether, and the number of recordings varies from language to language, with some having none. Whether prescriptives are used at all in a recording will depend on many factors external to the linguistic and even social ones. The fact that they have been found at all, and testified by fellow linguists, should be considered sufficient proof of their existence.

7. She says in the comments section of her Facebook posting: Jeg har faktisk sans for Ari 'I actually like Ari'.

8. One reviewer, Reviewer A, finds it totally unacceptable and insulting ('sterkt nedvurderande') to use this type of sentence to adults. There may be dialectal differences here. I do not know who the reviewer is, including his/her background, but I know that the English lecturer and myself are from different parts of Norway, and to me her posting is fine, with the knowledge of her superiority as an English academic, and her fondness for him. This satisfies the requirements for a social hierarchy and an amiable atmosphere.

Reviewer A (and others he has talked to about this) has the intuition that the reflexive 3SG with the prescriptive infinitive can only be used towards those that cannot respond (babies or animals). If, however, the reflexive is $2 \mathrm{SG}$, then it can be used freely towards adults, and is friendlier than the imperative, as in the following:

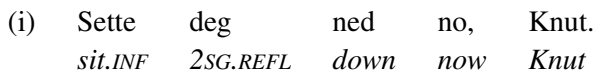

'Sit down now, Knut.'

Perhaps there is a dialectal difference here, or perhaps there is yet another distinction. A full dialectal investigation is beyond the scope of the present paper, and further studies 
are needed. However, the main point here is that Reviewer A, too, acknowledges the child-directed prescriptive infinitive (when used with 3SG).

9. Thanks to Urd Vindenes for this example.

10. Thanks to Kjersti Kola for this example.

11. Here is the direct citation from Heltoft \& Hansen (2011:738): 'Infinitiv i imperativisk funktion markerer at den talende er i en styrkeposition i forhold til modtageren; derfor er den ikke altid let at bruge til voksne'.

12. It seems (recall Reviewer A in note 8 and this section) that at least one Norwegian variety and Icelandic might be open to adult-directed prescriptive infinitives as long as the intention is friendliness. This requires more study.

13. The person of the subject of the prescriptive infinitives depends on the hierarchical status of the addresse; adult or a child (thanks to Eiríkur Rögnvaldsson, p.c.). To an adult, both subjects are possible, as witnesses by the reflexive pronoun:

$\begin{array}{llll}\text { (i) Ekki } & \text { pvo } & \text { pér / } & \text { sér! } \\ \text { not } & \text { wash.INF } & \text { 2.REFL } & 3 . R E F L\end{array}$

'Don't wash yourself!'

The positive prescriptive infinitive can only be used towards children, and with third person reflexives only:

$\begin{array}{lll}\text { (ii) } & \text { pvo } & \text { *bér / sér! } \\ \text { wash.INF } & \text { 2.REFL } & 3 . R E F L \\ \text { 'Wash yourself!' } & \end{array}$

14. There are also examples of child-directed DPs for second person in finite sentences in English:

(i) How is my baby/darling/dear/dearest/love/sweatheart/sweetie tonight?

(Collins \& Postal 2012:7)

15. Swedish and Norwegian also have one-syllable verbs ending in a vowel, and for these the infinitive is always the same as the imperative, as in (i).
(i) a. gå
walk.IMP/INF
b. sy
SOW.IMP/INF
(Norwegian)

16. The editor, Marit Julien, also points out that in the Trøndelag area such verbs can be pronounced in a different way, with a vowel being introduced in the problem consonant cluster in the imperative and the infinitive:

$\begin{aligned} \text { (i) } \operatorname{sykl} & \rightarrow \text { sykkel }(=\text { infinitive in this dialect }) \\ \text { klatr } & \rightarrow \text { klatter }(=\text { infinitive in this dialect })\end{aligned}$

17. While Norwegian is used in this analysis, the same could be held for Icelandic, even though this language distinguishes case on nouns, too. It is the nominative form that is used in the subject position of these prescriptive imperatives. This might be understood as undermining the current proposal. But it should be noted that nominative is also the unmarked form, often called 'telephone directory case' (Thorhallur Eythorsson, p.c.).

18. It should be mentioned that when Russian infinitives are used (in various pragmatic contexts), their subjects do not have nominative case, the argument must be dative: 
(i)

$\begin{array}{lll}\text { Kuda } & \text { nam } & \text { poekhat'? } \\ \text { where } & \text { us.DAT } & \text { go.INF }\end{array}$

'Where should we go?' (lit.: 'Where for us to go?')

(ii) Studentam ne kurit'.

student.PL.DAT not smoke.INF

'Students (must) not smoke (here).'

(On dative arguments with infinitive, see Timberlake 2004.) Again, this shows that there is no ordinary structural case-marking going on in infinitival sentences. (Thanks to Atle Grønn, p.c.)

19. Abusch's notation can be explained thus: $(x, y)$ is the interval from $x$ (left boundary, LB) to $\mathrm{y}$ (right boundary, RB). P is applied on an interval: (now, straight after). Put another way:

Fut = lambda $\mathrm{P}$. there is a t. $\mathrm{P}(\mathrm{t}) \& \mathrm{LB}(\mathrm{t})=$ now $\& \mathrm{RB}(\mathrm{t})=$ is a contextually given time shortly after $\mathrm{LB}(\mathrm{t})$.

I am grateful to Atle Grønn (p.c.) for assisting in the rendering of Abusch to the present purpose.

\section{CORPORA AND DATABASES}

Anderssen Child Language Corpus: Provided by Merete Anderssen, University of Troms $\emptyset$.

Childes Corpus, Norwegian, Swedish and Danish parts http://childes.psy.cmu.edu/ browser/index.php?url=Germanic/

CorpusEye Danish Corpus from the Newspaper Information http://corp.hum.sdu.dk/cqp.html

Icelandic Text Corpus; Íslenskt textasafn Stofnun Árna Magnússonar í íslenskum fræðum http://www.lexis.hi.is/corpus/leit.pl?allt=\&hreinsaform $=\mathrm{N} \% \mathrm{C} 3 \% \mathrm{BD}+\mathrm{leit}$

Lexicographical Bokmål Corpus http://www.hf.uio.no/iln/tjenester/kunnskap/sprak/ korpus/skriftsprakskorpus/lbk/index.html

Løver, Morten Aase \& Bror-Magnus Sviland Strand. 2015. N-LARSP corpus.

Merriam-Webster's Online Dictionary http://www.merriam-webster.com/dictionary/

Nordic Dialect Corpus http://www.tekstlab.uio.no/nota/scandiasyn/

Nordic Syntax Database http://www.tekstlab.uio.no/nota/scandiasyn/

\section{REFERENCES}

Aasen, Ivar. 1848. Det norske Folkesprogs Grammatik. [New printed version, Volda: Høgskulen i Volda, 1996]

Aasen, Ivar. 1864. Norsk grammatikk. Christiania. [Electronic version, Oslo: Det Norske Samlaget 1997]

Abusch, Dorit. 1985. On Verbs and Time. Ph.D. dissertation, University of Massachusetts Amherst.

Abusch, Dorit. 1988. Sequence of Tense, Intensionality, and Scope. In Hagit Borer (ed.), Proceedings of the Seventh West Coast Conference on Formal Linguistics (WCCFL 7), 1-14. Stanford, CA: CSLI Publications. 
Abusch, Dorit. 2004. On the temporal composition of infinitives. In Jacqueline Gueron \& Jacqueline Lecarme (eds.), The Syntax of Time, 27-53. Cambridge, MA: MIT Press. Aikhenvald, Alexandra Y. 2013. Imperatives and Commands. Oxford: Oxford University Press.

Alcázar, Asier \& Mario Saltarelli. 2014. The Syntax of Imperatives (Cambridge Studies in Linguistics 140). Cambridge: Cambridge University Press.

Alvestad, Silje Susanne. 2013. Beware of Fakes! Fake Imperfectives in the Slavic Imperative. Ph.D. thesis, Faculty of Humanities, University of Oslo.

Auwera, Johan van der \& Ludo Lejeune (with Valentin Goussev). 2013. The prohibitive. In

Matthew S. Dryer \& Martin Haspelmath (eds.), The World Atlas of Language Structures Online. Leipzig: Max Planck Institute for Evolutionary Anthropology. Available online at http://wals.info/chapter/71, accessed on 23 August 2016.

Bennis, Hans. 2006. Agreement, PRO and imperatives. In Peter Ackema, Patrick Brandt, Maaike Schoorlemmer \& Fred Weerman (eds.), Arguments and Agreement, 101-123. Oxford: Oxford University Press.

Bennis, Hans. 2007. Featuring the subject in Dutch imperatives. In van der Wurff (ed.), 113-134.

Bianchi, Valentina. 2003. On finiteness as logophoric anchoring. In Jacqueline Guéron \& Liliane Tasmowski (eds.), Temps et Point de Vue/Tense and Point of View, 213-246. Paris: Université Paris X Nanterre.

Chomsky, Noam. 1980. On Binding. Linguistic Inquiry 11, 1-46.

Chomsky, Noam. 1995. The Minimalist Program. Cambridge, MA: MIT Press.

Collberg, Sheila Dooley \& Gisela Håkansson. 1999. Negative imperatives and the typology of negation. Working Papers 47, 25-37. [Lund University, Department of Linguistics]

Collins, Chris \& Paul M. Postal. 2012. Imposters: A Study of Pronominal Agreement. Cambridge, MA: MIT Press.

Dørum, Hallvard. 2000. Preteritum konjunktiv i norske (og diverse andre) målføre. Norsk Lingvistisk Tidsskrift 18, 143-182.

Duden Grammatik der deutschen Gegenwartssprache. 1995. Mannheim: Dudenverlag.

Eide, Kristin Melum. 2002. Adjunction sites for negation in Norwegian modals and negation. Nordic Journal of Linguistics 25, 225-252.

Eide, Kristin Melum. 2009. Finiteness: The haves and the have-nots. In Artemis Alexiadou, Jorge Hankamer, Thomas McFadden, Justin Nuger \& Florian Schäfer (eds.), Advances in Comparative Germanic Syntax (Linguistik Aktuell/Linguistics Today 141), 357-390. Philadelphia, PA: John Benjamins.

Eide, Kristin Melum. 2011. The ghost of the Old Norse subjunctive: The Norwegian subjunctive participle. Groninger Arbeiten zur germanistischen Linguistik 53(2), $1-28$.

Eide, Kristin Melum. 2016. Why English isn't Norwegian: Finiteness, inflection, and the syntax your morphology can afford. Ms., Norwegian University of Science and Technology, Trondheim.

Einarsson, Stefán. 1967. Icelandic: Grammar, Texts, Glossary. Baltimore, MD: Johns Hopkins Press.

Faarlund, Jan Terje. 2004. The Syntax of Old Norse. Oxford: Oxford University Press.

Faarlund, Jan Terje, Svein Lie \& Kjell Ivar Vannebo. 1997. Norsk referansegrammatikk. Oslo: Universitetsforlaget.

Garbacz, Piotr \& Janne Bondi Johannessen. 2013. Negation in imperative clauses. Nordic Atlas of Language Structures (NALS) Online. http://tekstlab.uio.no/nals. 
Gärtner, Hans-Martin. 2013. Infinite Hauptsatzstrukturen. In Jörg Meibauer,

Markus Steinbach \& Hans Altmann (eds.), Satztypen des Deutschen, 202-231. Berlin: de Gruyter.

Hansen, Erik \& Lars Heltoft. 2011. Grammatik over det Danske Sprog, bind I-III. Odense:

Det Danske Sprog- og Litteraturselskab og Syddansk Universitetsforlag.

Haugen, Einar. 1982. Oppdalsmålet: innfфring i et sфrtrøndsk fjellbygdmål. Oslo:

Tanum-Norli.

Helland, Hans Petter. 2006. Ny fransk grammatikk: morfologi, syntaks og semantikk. Oslo: Universitetsforlaget.

Huldén, Lars. 1996. Berättelser i urval 1979-1996. Helsinki: Schildts \& Söderströms.

Iatridou, Sabine. 2008. De Modo Imperativo. Paris: ENS Lecture Notes. http://web.mit.edu/ linguistics/people/faculty/iatridou/publications.html (accessed 29 August 2016).

Jespersen, Otto. 1924. The Philosophy of Grammar. London: George, Allen and Unwin.

Johannessen, Janne Bondi, Joel Priestley, Kristin Hagen, Tor Anders Åfarli \& Øystein Alexander Vangsnes. 2009. The Nordic Dialect Corpus: An advanced research tool. In Jokinen \& Bick (eds.), 73-80.

Jokinen, Kristiina \& Eckhard Bick (eds.). 2009. Proceedings of the 17th Nordic Conference of Computational Linguistics NODALIDA 2009 (NEALT Proceedings Series Volume 4).

Tartu: Tartu University Library. http://hdl.handle.net/10062/9206.

Joseph, Brian D. \& Irene Philippaki-Warburton. 1987. Modern Greek (Croom Helm

Descriptive Grammar Series). London: Routledge.

Julien, Marit. 2003. Dobbelsupinum og irreal modus. Norsk Lingvistisk Tidsskrift 21, 135-161.

Landau, Idan. 1999. Elements of Control. Ph.D. dissertation, MIT.

Landau, Idan. 2000. Elements of Control: Structure and Meaning in Infinitival Constructions.

Dordrecht: Kluwer.

Larsen, Amund B. 1907. Kristiania bymål. Kristiania: Cammermeyer.

Larsen, Amund B. \& Gerhard Stoltz. 1912. Bergens bymål. Kristiania: Aschehoug.

Lee, Won-Kyu. 1991. Honorifics and Politeness in Korean. Ph.D. dissertation, University of Wisconsin-Madison.

Legate, Julie Anne. 2008. Morphological and abstract case. Linguistic Inquiry 39(1), $55-101$.

Lindstad, Arne Martinus. 2007. Analysis of Negation: Structure and Interpretation. Oslo: Acta Humaniora, Faculty of Humanities, University of Oslo.

Lindstad, Arne Martinus, Anders Nøklestad, Janne Bondi Johannessen \& Øystein Alexander Vangsnes. 2009. The Nordic Dialect Database: Mapping microsyntactic variation in the Scandinavian languages. In Jokinen \& Bick (eds.), 283-286.

Lubecka, Anna. 2000. Requests, Invitations, Apologies and Compliments in American English and Polish: A Cross-cultural Communication Perspective. Kraków: Księgarnia Akademicka.

McFadden, Thomas. 2008. Against abstract Case: Licencing versus selection of embedded subjects. Ms., Brandeis University.

Munch, Christine B. Østbø. 2013. North Germanic Negation: A Microcomparative Perspective. Ph.D. dissertation, University of Troms $\varnothing$.

Okada, Miyo. 1963. Keigo: Honorific Speech in Japanese. New Haven, CT: Yale University, Far Eastern Publications. 
Pedersen, Karen Margrethe. To appear. Dialektsyntaks. Dansk Sproghistorie.

Petersen, Hjalmar P. 2008. Tann nýggi noktandi boðshátturin í føroyskum, Íslenskt Mál 30, 141-152.

Platzack, Christer \& Inger Rosengren. 1998. On the subject of imperatives: A Minimalist account of the imperative clause. The Journal of Comparative Germanic Linguistics 1, $177-224$.

Poletto, Cecilia \& Raffaella Zanuttini. 2003. Making imperatives: Evidence from Central Rhaetoromance. In Christina Tortora (ed.), The Syntax of Italian Dialects, 175-207. New York \& Oxford: Oxford University Press.

Postma, Gertjan \& Wim van derWurff. 2007. How to say no and don't: Negative imperatives in Romance and Germanic. In van der Wurff (ed.), 205-249.

Rice, Curt. 2003. Dialectal variation in Norwegian imperatives. Nordlyd 31(2), 372-384.

Ritter, Elizabeth \& Martina Wiltschko. 2014. The composition of INFL: An exploration of tense, tenseless languages and tenseless constructions. Natural Language \& Linguistic Theory 32, 1331-1386.

Ross, John R. 1970. On declarative sentences. In Roderick A. Jacobs \& Peter S. Rosenbaum (eds.), Readings in English Transformatinal Grammar. 222-272. Waltham, MA: Ginn and Co.

Sandøy, Helge. 1991. Attraksjon av supinum i færøysk og norsk. Danske folkemål 3, 251-262.

Sigurðsson, Halldór Ármann. 2001. Case: Abstract vs. morphological. Working Papers in Scandinavian Syntax 67, 103-151.

Sigurðsson, Halldór Ármann. 2004. The syntax of Person, Tense, and Speech features. In Valentina Bianchi \& Ken Safir (eds.), The Syntax and Interpretation of Person Features: Special issue of Rivista di Linguistica 16(1), 219-251.

Sigurðsson, Halldór Ármann. 2010. Mood in Icelandic. In Björn Rothstein \& Rolf Thieroff (eds.), Mood in the Languages of Europe. Amsterdam: John Benjamins.

Sigurðsson, Halldór Ármann. 2014. Context-linked grammar. Language Sciences 46, $175-188$.

Språkrådet 2015, on the imperative: http://www.sprakradet.no/sprakhjelp/ Praktisk-grammatikk/Imperativ/ (accessed 29 August 2016).

Stowell, Tim. 1982. The tense of infinitives. Linguistic Inquiry 13, 561-570.

Sundaresan, Sandhya \& Thomas McFadden. 2009. Subject distribution in Tamil and other languages: Selection vs. case. Journal of South Asian Linguistics 2(1), 5-34.

Teleman, Ulf, Staffan Hellberg \& Erik Andersson. 1999. Svenska akademiens grammatik, 4 vols. Stockholm: Svenska Akademien.

Thráinsson, Höskuldur. 2007. The Syntax of Icelandic. New York: Cambridge University Press.

Thráinsson, Höskuldur, Hjalmar P. Petersen, Jógvan Í Lon Jacobsen \& Zakaris Svabo Hansen. 2004. Faroese: An Overview and Reference Grammar. Tórshavn: Føroya Fróðskaparfelag.

Timberlake, Alan. 2004. A Reference Grammar of Russian. Cambridge: Cambridge University Press.

van der Wurff, Wim (ed.). 2007. Imperative Clauses in Generative Grammar. Amsterdam: John Benjamins.

Wierzbicka, Anna. 1985. Different cultures, different languages, different speech acts: Polish vs. English. Journal of Pragmatics 9, 145-178.

Wurmbrand, Susi. 2014. Tense and aspect in English infinitives. Linguistic Inquiry 45(3), 403-447. 
Zanuttini, Rafaella. 1996. On the relevance of tense for sentential negation. In Adriana Belletti \& Luigi Rizzi (eds.), Parameters and Functional Heads, 181-207. New York: Oxford University Press.

Zanuttini, Rafaella. 2008. Encoding the addressee in the syntax: Evidence from English imperative subjects. Natural Language \& Linguistic Theory 26(1), 185-218. 